\title{
Pedagogical Innovations and Estonian Education at the Beginning of the Nineteenth Century: Transnational Influences and Historical Roots
}

\author{
Aivar Pôldvee \\ Tallinn University, School of Humanities, Centre of History, \\ Archaeology and Art History, Uus-Sadama 5, IOI2o Tallinn, \\ aivar.poldvee@tlu.ee
}

\begin{abstract}
The article focuses on Estonian schools' first contacts with the educational innovations of the Enlightenment at the beginning of the nineteenth century. New pedagogical ideas and methods of teaching, which spread through transnational networks of intellectuals and the written word, reached Estonian (and Latvian) peasants, mainly via clergymen. The ideas of Johann Heinrich Pestalozzi were highly valued by Georges Frédéric Parrot, adviser to emperor Alexander I. The vocational school founded by Ferdinand Kindermann served as an example for the parish school opened by Johann Philipp von Roth, pastor at Kanepi. Otto Wilhelm Masing, pastor at Äksi, tried to adapt the Bell-Lancaster method first launched in India and England to Estonian schools. In addition to a transnational perspective, the article makes comparisons with the seventeenth century, when attempts were made to solve similar problems when educating peasants in Estland and Livland.
\end{abstract}

Keywords: Enlightenment; Reformpädagogik; progressive education; pedagogical innovations; Pestalozzi; Industrieschule; Bell-Lancaster system; phonic method; Estonian school; Otto Wilhelm Masing 


\section{INTRODUCTION}

Educational institutions characteristic of the European societies of the modern period were formed on the territory of the present-day Estonia during the Lutheran Swedish rule of the seventeenth century. At the beginning of the I630s a gymnasium was founded in Tallinn (Ger. Reval) and a university in Tartu (Ger. Dorpat); in the mid-I68os a breakthrough was achieved in people's education in the countryside. In less than ten years Estonian schoolmasters were trained and a network of parish schools was created. This process can be regarded as part of the so-called Swedish literacy campaign, which had a focus on reading skills, ${ }^{\mathrm{I}}$ during which an educational programme organised by the Lutheran church strongly influenced by German models was quite successfully carried out, first of all the New Testament was translated into Estonian and common people were taught to read it. ${ }^{2}$ Rural schools were established with great enthusiasm and the first schoolmasters were trained in the so-called Forselius Seminar, which operated for two years. Additionally, schools were provided with the necessary textbooks (mainly primers, catechisms and hymnbooks). ${ }^{3}$ During the Great Northern War (1700-172I), the Baltic provinces of Sweden went under Russian rule in I7Io. The capitulations of the cities and the Baltic German knighthoods (Ritterschaften) approved by the Russian tsar Peter I guaranteed the continuation of Lutheranism and extensive self-rule; Swedish Church Law was in force (with minor amendments) until I $832 .{ }^{4}$ Church authorities and especially clergymen influenced by Pietism ${ }^{5}$ tried to maintain and expand the school network in the rural areas, but due to the hard economic circumstances of the end of the seventeenth century and

I Johansson, E. Literacy Campaigns in Sweden. - National Literacy Campaigns. Historical and Comparative Perspectives. Ed. by R. F. Arnove, H. J. Graff. Springer, New York, 1987, $65-98$.

2 Beyer, J. Strategien zur Hebung der Frömmigkeit in Est- und Livland (162I-I710). Konfessionalisierung und Pietismus. - Confessionalism and Pietism. Religious Reform in Early Modern Europe. Ed. by F. van Lieburg. (Veröffentlichungen des Instituts für Europäische Geschichte, 67.) Von Zabern, Mainz, 2006, III-I28; Póldvee, A. Die langsame Reformation: Luthertum, Schrifttum und die estnischen Bauern im I6.-17. Jahrhundert. Wandel und Anpassung in der Geschichte Estlands. 16.-20. Jahrhundert. Ed. by K. Brüggemann. (Nordost-Archiv: Zeitschrift für Regionalgeschichte, XXII/2013.) Nordost-Institut, Lüneburg, 20I4, 56-88.

3 Wieselgren, G. B. G. Forselius und die Grundlegung der estnischen Volksschule. Urkunden und Kommentar. - Vetenskapssocieteten i Lund. Årsbok (1942). Gleerup, Lund, 1943, 66-I28; Póldvee, A. Peasant Schools in Estland and Livland during the Last Quarter of the 17th Century. - Common Roots of the Latvian and Estonian Literary Languages. Ed. by K. Ross, P. Vanags. Peter Lang, Frankfurt am Main, 2008, 6I-99.

4 Andresen, A. Luterlik territoriaalkirik Eestimaal I7IO-I832. Riigivôimu môju kirikuvalitsemisele, -institutsioonidele ja -ôigusele. (Dissertationes historiae Universitatis Tartuensis, 7.) Tartu Ülikool, Tartu, 2004.

5 See Sild, O. August Hermann Francke' môjud meie maal. [n. p.], Tartu, 1928. 
the prevailing crisis of serfdom, the school network was on the verge of collapse across Estonian territory; only in Tartu and Vóru (Ger. Werro) counties had most of the village schools survived. ${ }^{6}$

During the same period, more and more social and pedagogical ideas influenced by the Enlightenment reached the Baltic provinces, along with popular Enlightenment ideas promoting peasant emancipation. ${ }^{7}$ The era of the Enlightenment is characterised by unprecedented activity and pursuit of new ideas in the field of didactics and education; innovative pedagogues became international celebrities, whose works and textbooks were eagerly awaited, whose schools were visited and held up as examples, and whose methods were followed and developed. The German progressive educationalist Joachim Heinrich Campe (1746-I8I8) described the era of Enlightenment as "a pedagogical century". "The ideas of this "century" and of progressive education (Ger. Reformpädagogik) also reached the Baltic provinces. However, detailed research into the question of what kind of response the pedagogical ideas of the Enlightenment found in Estland and Livland provinces was started only a couple of decades ago. Indrek Jürjo has pointed out that heightened interest in the questions of education and upbringing was also experienced in the Baltic provinces, the educational ideas of Western Europe were closely followed, and Rousseau's Émile was diligently read and sometimes even used as an example while raising children. For parents from affluent circles - mainly noblemen, the educated social ranks, the so-called literati and merchants - offering one's children the best and preferably the most modern education and upbringing was almost the ultimate purpose of life. They tried hard to find for their children capable and educated tutors and governesses, who were in high demand in the Baltic countries, and even sent their children to learn in German education institutions. For example, every fifth student at Johann Bernhard Basedow's (1724-1790) Philanthropinum in Dessau was of Baltic descent. ${ }^{9}$ In his ground-breaking research on the reception

6 Eesti kooli ajalugu. I. köide: I3. sajandist I860. aastateni. Toim E. Laul. Valgus, Tallinn, 282-284.

7 See Wilpert, G. von. Deutschbaltische Literturgeschichte. C. H. Beck, München, 2005, IO3-II2, I4O-I44; Hasselblatt, C. Geschichte der estnischen Literatur. Von den Anfängen bis zur Gegenwart. Walter de Gruyter, Berlin, New York, 2006, I50-172; Daija, P. Literary History and Popular Enlightenment in Latvian Culture. Cambridge Scholars Publishing, Newcastle upon Tyne, 20I7.

8 See Schindling, A. Bildung und Wissenschaft in der Frühen Neuzeit 1650-180o. (Enzyklopädie deutscher Geschichte, 30.) Oldenbourg, München, 1999, 77-88 (chapter "Ein pädagogisches Jahrhundert? - Gymnasium und Volksschule, Lesen und Schreiben"); Pädagogische Volksaufkärung im I8. Jahrhundert im europäischen Kontext: Rochow und Pestalozzi im Vergleich. Hrsg. von H. Schmitt, R. Horlacher, D. Tröhler. Haupt, Bern, Stuttgart, Wien, 2007.

9 Tering, A. Eesti-, liivi- ja kuramaalased Euroopa ülikoolides I56I-1798. Eesti Ajalooarhiiv, Tartu, 2008, I52-I53. 
of the new educational ideas in Tallinn during the third quarter of the eighteenth century, Jürjo reached the conclusion that German progressive education was quite well known and widely discussed, although philanthropic experiments were treated with caution. ${ }^{10}$ Although the history of peasant schools (Volksschule) as institutions in the eighteenth and nineteenth centuries has been researched for a long time, and quite thoroughly, the question of how the new ideas about education reached the peasantry has only been lightly touched upon. ${ }^{11}$ The present article is the first attempt to chart these problems and place them in the context of transnational studies.

Researching the history of education from the perspective of transnational history has produced the first comprehensive results. Due to the "transnational turn", researchers of the history of pedagogics have included terms like "globalization", "transnational space”, etc., in their vocabulary; these terms replace or enhance the earlier terms "international”, "intercultural”, "cultural transfer”, histoire croisée or "shared history". ${ }^{12}$ However, the "transnational turn" occasionally seems to be limited to just changing labels, as international and transnational context has always been the natural prerequisite and inevitable methodological approach for the history of education, at least as far as its best achievements are concerned. One of the initiators and leading figures of research on the spread of transnational networks and the intellectuals' ideas was Ján (Johannes) Radomil Kvačala, a professor of religious studies at Tartu University between 1893 and 1917. His research focussed on John Amos Comenius (Jan Amos Komenský), one of the most influential pedagogues of the seventeenth century; the present-day discipline of

Io Jürjo, I. Die Bildungsreformen und Diskussionen in Reval im letzten Drittel des I8. Jahrhunderts. - Baltische Literaturen in der Goethezeit. Hrsg. von H. Bosse, O.-H. Elias,

T. Taterka. Königshausen \& Neumann, Würzburg, 20II, 38I-4II.

II See Berkholz, C. A. Veranlaßte Erläuterungen zur Geschichte der Bauerschulen in Livland. Müllersche Buchdruckerei, Riga, I879; Speer, H. Das Bauernschulwesen im Gouvernement Estland vom Ende des achtzehnten Jahrhunderts bis zur Russifizierung. J. G. Krüger, Tartu, 1936; Schaudinn, H. Deutsche Bildungsarbeit am lettischen Volkstum des I8. Jahrhunderts. Reinhardt, München, I937; Eesti kooli ajalugu. I. köide, 9I-98 (overview about pedagogical thought by A. Elango). L. Andresen presented more extensive treatments of pedagogical ideas, but his descriptions lack scientific accuracy. See Andresen, L. Eesti rahvakooli ja pedagoogika ajalugu. 4 kd. Avita, Tallinn, 1997-2007.

I2 The Transnational in the History of Education: Concepts and Perspectives. Ed. by E. Fuchs, E. Roldán Vera. Palgrave Macmillan, Cham, Switzerland, 2019 (see especially Fuchs, E., Roldán Vera, E. Introduction: The Transnational in the History of Education, I-47; Mayer, C. The Transnational and Transcultural: Approaches to Studying the Circulation and Transfer of Educational Knowledge, 49-68); Zirkulation und Transformation. Pädagogische Grenzüberschreitungen in historischer Perspektive. Hg. v. Caruso, M., Koinzer, T., Mayer, C., Priem, C. (Beiträge zur historischen Bildungsforschung, 44.) Böhlau, Cologne [etc.], 2013 (see especially Lawn, M. Awkward Knowledge: The Historian of Education and Cross-Border Circulations, I5-27; Mayer, C. Zirkulation und Austausch pädagogischen Wissens: Ansätze zur Erforschung kultureller Transfers um I8oo, 29-49). 
comeniologic studies (Ger. Comenologie) is named after him. ${ }^{13}$ Peeter Pôld, the first Estonian Minister of Education and the first Estonian professor of pedagogics at Tartu University, was among Kvačala's students. ${ }^{14}$ Today, several projects follow Kvačala's principles, for example, Networking the Republic of Letters, I550-1750 (University of Oxford); Mapping the Republic of Letters: Exploring Correspondence and Intellectual Community in the Early Modern Period (I500-I80o) (Stanford University), etc. ${ }^{15}$

The international circulation of ideas via printed matter and through the networks of res publica litteraria or the freemasons represent the communicative aspect of the topic. The fact that the Baltic provinces of the eighteenth century were part of the wider northeastern European communication system, has already been pointed out by Heinz Ischreyt, Indrek Jürjo and others. ${ }^{16}$ Arvo Tering has thoroughly researched students from Estland, Livland and Courland in European universities, creating a broad panorama of their academic stimuli and networks. ${ }^{17}$ Due to their geographical position, the Baltic provinces have always been a locus of contacts and interfusions of different nationalities, cultural influences and ideas fostering transmission and hybridity. At the same time, the internal social, hierarchic and linguistic barriers and preconceptions demanded conscious and determined efforts of those who wished to overcome them, with those who promoted people's education and enlightenment playing a significant role in this.

I3 Kvačala, J. Die pädagogische Reform des Comenius in Deutschland bis zum Ausgange des XVII. Jahrhunderts. Bd. I, Texte; Bd. 2, Historischer Überblick, Bibliographie, Namenund Sachregister. A. Hofmann \& comp., Berlin, 1903-1904; Analecta Comeniana. Collegit Ioannes Kvačala. Typis Mattiesenianis, Iurievi [Tartu], 1909; Kvacsala, J. Johann Amos Comenius. Sein Leben und seine Schriften. J. Klinkhardt, Berlin, Leipzig, Wien, I892; Kvačala, J. J. A. Comenius. Reuther \& Reichard, Berlin, I9I4. See Schwarz, K. W. Ján Kvačala ja tema tähendus Tartu/Dorpati ülikoolile. - Eesti teoloogilise môtlemise ajaloost: Sissejuhatavaid märkusi ja apokrüüfe. Koost R. Altnurme. Tartu Ülikooli Kirjastus, Tartu, 2006, 72-83.

I4 See Peeter Póld oma ajastu peeglis. Koost H. Muoni. Tartu Ülikooli kirjastus, Tartu, I996; Póld, P. Eesti kooli ajalugu. Akadeemiline Kooperatiiv, Tartu, 1933.

I5 http://www.culturesofknowledge.org/; http://republicofletters.stanford.edu/publications/ index.html.

I6 Ischreyt, H. Buchhandel und Buchhändler im nordosteuropäischen Kommunikationssystem (1762-1797). - Buch und Buchhandel im I8. Jahrhundert. Hrsg. von G. Barber, B. Fabian. Dr. Ernst Hauswedell \& Co. (Wolfenbütteler Schriften zur Geschichte des Buchwesens, 4.) Hamburg, I98I, 249-26o; Jürjo, I. Lesegesellschaften in den baltischen Provinzen im Zeitalter der Aufklärung. Mit besonderer Berücksichtigung der Lesegesellschaft von Hupel in Oberpahlen. Teil I. - Zeitschrift für Ostforschung, 1990, 39, 4, 540-571; Wistinghausen, H. v. Freimaurer und Aufklärung im Russischen Reich. Die Revaler Logen I773-1820. 3. Bd. Mit einem biographischen Lexikon. Böhlau, Cologne [etc.], 2016.

I7 Tering, A. Eesti-, liivi- ja kuramaalased; Tering, A. Lexikon der Studenten aus Estland, Livland und Kurland an europäischen Universitäten I56I-I80o. Unter Mitarbeit v. J. Beyer. (Quellen und Studien zur baltischen Geschichte, 28.) Böhlau, Cologne [etc.], 2018. 
The field of the history of ideas also includes a vertical dimension: solutions, methods and concepts invented at previous stages can be re-used or re-invented, should the historical circumstances recur. The obstacles met in educating Estonian peasants and promoting the Estonian written language at the end of the eighteenth and at the beginning of the nineteenth centuries were quite similar to the problems for which solutions had already been sought during the last quarter of the seventeenth century, although a hundred years had passed and the context had changed. Swedish rule had been replaced by Russian rule and the educational programme of the Reformation replaced with the Enlightenment and people's education, although peasants were still serfs and the limits of their education and freedom were determined by the German-speaking elite, i.e. the nobility and the clergy. The main topics of the present article are related to the author's earlier research in the field of the history of education, and although they mainly deal with the early modern period, ${ }^{18}$ they help to explore the questions from a new angle. The article focuses on the earliest manifestations of progressive education in the teaching of Estonian peasants, mainly on Otto Wilhelm Masing's pedagogical activities, which emphasise both didactic and linguistic aspects. This has also determined the range of sources the article is based on and its interdisciplinary approach.

\section{JOHANN HEINRICH PESTALOZZI AND THE BALTIC PROVINCES}

Rousseau's Émile described questions of education from the viewpoint of the wealthy elite, but positions of the Swiss pedagogue Johann Heinrich Pestalozzi (1746-1827) were closer to the common people. It would therefore be appropriate to briefly describe the indirect influence of Pestalozzi's ideas in the Baltic provinces, where he had ardent admirers who sent their children to study under him. In I808, Pestalozzi's education institution for boys (Pestalozzische Lehranstalt für Knaben) was opened in Riga and was the first of its kind in Russia. ${ }^{19}$ Pestalozzi's novel

I8 Póldvee, A. Viis aabitsat ja Forseliuse ôppeviis. - Lugemise kunst $=$ The Art of Reading. Koost P. Lotman. Eesti Rahvusraamatukogu, Tallinn, 20II, 60-I22; Póldvee, A. 17th Century Estonian Orthography Reform, the Teaching of Reading and the History of Ideas.

- Trames. Journal of the Humanities and Social Sciences, 20II, I5, 4, 365-384.

I9 About Pestalozzi's connections to Estonia and Livonia: Elango, A. J. H. Pestalozzi ja Eesti. - Nôukogude Kool, 1984, 3, 34-36; Andresen, L. Eesti rahvakooli ja pedagoogika ajalugu III. Koolireformid ja venestamine (I803-I9I8). Avita, Tallinn, 2002, 25-3I; Zigmunde, A. Die Beziehungen Johann Heinrich Pestalozzis zu Lettland. RTU, Riga, 20Io; Busch, N. Geschichte der Literärisch-praktischen Bürgerverbindung in Riga I802-1902. Spezieller Teil: Die Anstalten der Bürgerverbindung. I: Die Schulen. W. F. Häcker, Riga, 1902, 55-56. 
Lienhard und Gertrud. Ein Buch für das Volk (4 vols., 178I-1787) was a great international success that promoted home tuition - peasants' children were to be taught through household chores and activities, mainly by their mothers. Pestalozzi is one of the leading figures of pedagogics and is often referred to when people speak about the "educational turn". ${ }^{20}$ His ideas were implemented during the education reform of the Helvetic Republic, which created a state school system starting with primary schools. The reform was carried out by the Helvetian Directory, a member of which was Frédéric-César de La Harpe (1754-1838), the tutor and long-term mentor of future Russian emperor Alexander I. In I80o, Pestalozzi set up a teachers' seminar in Burgdorf to promote his methods of teaching. A few years later La Harpe informed emperor Alexander about this and suggested that the seminar could serve as an example for Russia. The culmination of Pestalozzi's educational activities was his institute in Yverdon (1805-1825), which received students and admirers from all over Europe. ${ }^{21}$

Among the elite of the Baltic provinces, baron Christoph Adam von Stackelberg (1777-I84I) had closest relations to Pestalozzi, as he practiced as Pestalozzi's assistant and visited Yverdon several times. ${ }^{22}$ From I819 to I834, Stackelberg was the director of the Tallinn Governorate Gymnasium, at the same time leading other public educational institutions as a governorate school director (Gouvernements-Schuldirektor) and a member of the permanent school committee of Estland (permanentes Volksschulkomitee Estlands), founded in I819. The nature- and work-based teaching method originating from Pestalozzi's ideas was first described in Estonian in the textbook Weikenne oppetusse nink luggemisse Ramat (A Little Reader and Book of Knowledge, I805) by Vastseliina (Ger. Neuhausen) pastor George Gottfried Marpurg (1755-I835) from Thuringia. ${ }^{23}$ Marpurg submitted the German version of his manuscript

20 See Tröhler, D. Pestalozzi and the Educationalization of the World. Palgrave Macmillan, New York, 20I3; Müller-Wieland, M., Schönebaum, H. Pestalozzis Beziehungen zu Österreich und Russland. Morgarten Verlag, Zürich, I962.

2I About the destinations of the trips of Baltic Germans in Switzerland see Tering, A. Eesti-, liivi- ja kuramaalased, 479-487.

22 Stackelberg's connections to Pestalozzi would need further study as the information available in the literature is contradictory. While staying with Pestalozzi, Stackelberg met Josephine Brunsvik, whom music historians consider to be Ludwig van Beethoven's Immortal Beloved. Josephine arrived in Yverdon with her two sons and Stackelberg became their tutor. In I8Io, Stackelberg and Josephine Brunsvik were married. See Hansen, G. v. Geschichtsblätter des Revalschen Gouvernements-Gymnasiums zu dessen 250-jährigem Jubiläum am 6. Juni I88I. F. Kluge, Reval, I88I, I25-I26, 217; Sämtliche Briefe an Johann Heinrich Pestalozzi. Kritische Ausgabe. Bd. II: I805-I809. Hrsg. von R. Horlacher, D. Tröhler. Walter de Gruyter, Berlin, New York, 2010, 572-573; Caeyers, J. Beethoven, A Life. University of California Press, Oakland, 2020, 236-239.

23 [Marpurg, G. G.] Weikenne oppetusse nink luggemisse Ramat Tarto ma-rahwa kooli laste tarbis. M. G. Grensius, Tarto, 1805. See Biographie. Georg Gottfried Marpurg. Das Inland, 1836, 40, 657-665, 4I, 673-682. 
to a competition announced in 1802 by the Livonian Common Weal and Economic Society (Livländische Gemeinnützige und Ökonomische Sozietät). It was awarded a prize, approved by the school committee of Tartu University in 1803 and published in the south Estonian language in I805. ${ }^{24}$ The main characters of the book are schoolmaster Andre and his wife Anne "from a parish in Livland", who are like a mother and father to the students. Lienhard and Gertrud, or even Pestalozzi himself and his wife Anna, during the Neuhof days, might have been used as examples here. In Marpurg's textbook, the students - apart from learning from books - help with housework and learn the handicrafts needed on the farm. For dinner, they eat potatoes and cabbages grown by Andre and Anne, and the teacher's wife shows the girls how to spin, weave and sew. Their lessons are structured as conversations between the schoolmaster and his students; they start from local nature and geography and end up with celestial bodies and God Almighty. Marpurg's textbook was the first schoolbook in the Estonian language that systematically shared elementary knowledge of the sciences. The same direction was continued by Karl Ernst von Berg's (I773-I833) ABC reader (I8II). ${ }^{25}$ So far, Marpurg's textbook has been described only briefly in general overviews of literature and school history, so its examples need further examination. ${ }^{26}$ There was no parish school in Vastseliina during Marpurg's time, but he founded a school at Róuge (Ger. Rauge) church, where he became a pastor in I8II.

The general picture of how the Enlightenment affected ideas on education in the Baltic provinces has been substantially enriched by Epi Tohvri in her recent voluminous research on Georges Frédéric Parrot (1767-1852), the first rector of the Imperial University of Tartu. ${ }^{27}$ Parrot came from the French protestant town of Montbéliard, studied at the University of Stuttgart (Academia Carolina), and arrived in 1795 in Livland at the invitation of Karl Eberhard von Sievers, owner of Cēsis (Ger. Wenden) castle and Vecate manor (Ger. Alt-Ottenhof) to become a tutor. One of Parrot's closest friends and supporters in Livland was

24 Oras, F. George Gottfried Marpurg. Ioo a. surmapäeva puhul. - Eesti Kirjandus, I935, I2, 534-535.

25 [Berg, K. E. v.] Uus ABD ja Luggemisse-Ramat. G. Markwardt, Perno, I8II.

26 Vinkel, A. Eesti rahvaraamat. Eesti Raamat, Tallinn, 1966, 58-60; Andresen, L. Eesti kooli vanem ajalugu. Valgus, Tallinn, 1985, I3I-I32; Matteus, A. Aufklärerische Literatur für estnische Kinder und Jugendliche. Deutsch-estnischer Kulturtransfer im Baltikum vom Ende des I8. bis Anfang des 19. Jahrhunderts. Teil I. - Kinder- und Jugendliteraturforschung, 20II/20I2. Ed. by B. Dolle-Weinkauff, H.-H. Ewers-Uhlmann, C. Pohlmann. Peter Lang, Frankfurt am Main (etc.), 2012, 18, 32-34.

27 Tohvri, E. Georges Frédéric Parrot. Tartu keiserliku ülikooli esimene rektor. Tartu Ülikooli kirjastus, Tartu, 2or9. 
Karl Gottlob Sonntag (1765-1827), senior pastor of St. Jacob's Church in Riga, an adherent of Pestalozzi's ideas and later Livland's Superintendent General (1803-1827) as well as an active promoter of peasant education. Parrot met the brightest members of the nobility in the Livonian Common Weal and Economic Society, and from the end of I795, coordinated the society's activities as its scientific secretary. Successful completion of the duties of the scientific secretary paved the way to becoming a professor and rector of the University of Tartu, re-opened in I802. One of the university's tasks was to organise education in the surrounding provinces on a wider scale. In I804, Parrot as the rector of the university asked Pestalozzi for help with the school reform, but Pestalozzi refused. ${ }^{28}$ Parrot's views on education were considerably more comprehensive than needed for the university, which was opened to promote the sciences and prepare the intellectual elite. In line with the Enlightenment and the economic theory of Physiocracy, he connected the ideas of opening the university with the need to abolish serfdom and with peasant emancipation: in his opinion, education had to help Estonian and Latvian peasants become full members of society, not remain the slaves of their compatriots. The native people had to be given the right to become judges, pastors or doctors; all public education and all positions, including the position of a man of letters (bomme de lettres) had to be accessible to them.

Before approaching particular cases, briefly about the background of school arrangements. In 1802 , the Ministry of Education was founded in Russia, and in 1803 the territory of the whole empire was divided into six school districts. Tartu University became the centre of one of the districts. Tartu was to solve the education questions in the Governorates of Estland, Livland and Courland and initially (until I8I2) the Vyborg Governorate. The first curator of the Tartu school district was Friedrich Maximilian von Klinger (1752-1831), the German dramatist whose play Sturm und Drang gave its name to an entire literary movement. A school commission consisting of seven members was founded at the university (active from I803 to I837), the members being rector Parrot and six full-time professors. The commission had to work out

28 The rumours that the tsar was planning to invite Pestalozzi to Tartu in connection with an institute to be opened there (a gymnasium?) reached Yveron in August I804. In a letter of 17 October I804, Parrot asked on behalf of the school commission for Pestalozzi's help in founding and managing schools. Pestalozzi received the letter on 13 January I805 and declined the offer on 22 January. Sämtliche Briefe an Johann Heinrich Pestalozzi. Kritische Ausgabe. Bd. I: 1764-1804. Hrsg. von R. Horlacher, D. Tröhler. Walter de Gruyter, Berlin, New York, 2009, 733-734, 755-756; compare Sämtliche Briefe an Johann Heinrich Pestalozzi. Bd. II, 19-20; Pestalozzi, J. H. Sämtliche Briefe. Hrsg. vom Pestalozzianum und der Zentralbibliothek in Zürich. Bd. 4. Orell Füssli, Zürich, 195I, 293. 
regulations for three levels of the school system: parish schools, county schools and gymnasiums. At the end of $\mathrm{I} 804$, according to the proposals collected, Parrot drew up a plan for how to arrange the system of statefunded parochial schools, but it was rejected by the General Directorate of Schools in Saint Petersburg. It was considered more practical to set up parish schools incrementally and on a voluntary basis, which was also the opinion expressed by the High Consistory of Livland as well as the Livland Knighthood. The High Consistory also wanted to avoid the conflict of competence that would have been caused by parish schools being subordinated to the university's school commission. Thus, discussions about the plan ended in deadlock. ${ }^{29}$

Rector Parrot considered his duties as a member of the school commission to be even more important than his professorship. In May I806, he wrote in a letter to Alexander I: "As I am unable to carry out the plan of parochial schools, I can say that for me, all kinds of other school make no sense, and I would be ashamed if I only produced scientists, as I would like to work to produce people instead." ${ }^{\prime 30}$ By that time, as an adviser to Alexander I, Parrot had achieved the same position that La Harpe had had before. In December of the same year, Parrot explained to the emperor the mentality of peasants in the Baltic provinces, which was becoming a topical question in connection with the Napoleonic wars and the need to summon land militia. Parrot mentioned that when Estonians and Latvians became subordinates of the Russian empire, their life under serfdom became more depressing and harder to bear. They are not connected to the Russian people and therefore exhibit no patriotism. To some extent, Estonians and Latvians do feel solidarity, but they still bewail the happier times they had under Swedish rule, and this kind of local mentality is just the opposite of what the empire would like to see. ${ }^{31}$

\section{JOHANN PHILIPP VON ROTH AND INDUSTRIESCHULE}

Two men stand out at the beginning of the nineteenth century in connection with pedagogical innovations in Estonian education, Johann Philipp von Roth (1754-1818) and Otto Wilhelm Masing. Roth, pastor of

29 Eesti kooli ajalugu. I. kd, 30I-308; Tohvri, E. Georges Frédéric Parrot, 589-598.

30 Tohvri, E. Georges Frédéric Parrot, 187-222, 570-572, 613-6I4.

3I Tohvri, E. Georges Frédéric Parrot, 246-247. See also Tannberg, T. Warten auf Napoleon. Die Landmiliz der Jahre I806-I807 in den baltischen Gouvernements des Zarenreichs. (Tartuer historische Studien, 4.). Dr. Kovač, Hamburg, 2015. 
Kanepi (Ger. Kannapäh), can be considered a predecessor of Masing, who was nine years younger. ${ }^{32}$ Both were involved in the first steps of Estonian-language journalism, aimed at enlightening the people. Together with Gustav Adolph Oldekop, pastor of Pólva (Ger. Pölwe), and Carl August von Roth, inspector of schools in Vorru (Ger. Werro), Johann Philipp von Roth published the weekly Tarto maa rahwa Näddali-Leht (Tartu County Peasants' Weekly), which started circulating in 1806 and was promptly forbidden in the same year. ${ }^{33}$ Later, Masing published and edited the newspaper Marahwa Näddala-Leht (Peasants' Weekly).

At the end of 1804 , when the school commission of the university was drawing up a plan for founding schools, Roth at his own initiative opened a parochial school at Kanepi church for I2- to I8-year-old boys. In earlier Estonian historical research, this school has often been highlighted as the first Estonian parish school, ignoring the fact that the schools founded at country churches at the end of the seventeenth century were also parochial schools. The comparison with the seventeenth century was drawn by Karl Gottlob Sonntag, who compared Roth with Johann Fischer, Superintendent General of Livland, and Ernst Glück, the pastor of Alūksne (Ger. Marienburg), who both have considerable merits in founding Latvian schools. ${ }^{34}$ At Kanepi school, the curriculum was more comprehensive than at previous schools, including nature studies and an introduction into geography and history, but also the agricultural work and handicraft needed in farms together with joinery and book binding. This kind of production was called the parish school industrial branch (Industriezweig). Tools and equipment for handicraft were ordered from England and Germany and the production was used to maintain the school. At school, free time was spent with games, gymnastics and swimming. In I8II, Roth founded a so-called charity and vocational school (Armen-und Industrieschule) for II- to I4-year-old girls with, again, the costs of the school partly covered by selling the girls' handicraft. Roth even presented empress Elizabeth Alexeievna with a straw hat made by the girls.

There are numerous descriptions of Roth's schools, ${ }^{35}$ but the question of his pedagogical influences has not yet been researched. Peeter

32 Sild, O. Johann Philipp von Roth. - Eesti Üliốpilaste Seltsi album. 7. leht. Eesti Üliópilaste Selts, Tartu, I902, 139-166; Johann Philipp von Roth. Koost M. Hirvlaane. [M. Hirvlaane], Tartu, 200o; Salupere, M. Meie esimene matsileht, esimene kutseóppeasutus ning nende asutaja pastor J. Ph. von Roth. - Keel ja Kirjandus, 1996, 8, 514-520; 9, 590-600.

33 Tarto maa rahwa näddali-leht [säilinud numbrid]. Koost T. Tannberg. [Eesti Ajalooarhiiv, Tartu], [1998]; Tarto maa rahwa näddali-leht. Uurimusi ja allikmaterjale. Koost T. Tannberg. Eesti Ajalooarhiiv, Tartu, 1998.

34 Sonntag, K. G. Nachtrag zu den Erinnerungen an Roth. - Magazin für protestantliche Prediger, vorzüglich im Russischen Reiche. J. C. D. Müller, Riga, I8ı18, 373.

35 Sonntag, [K. G.] Die Kannapähischen Schulen. - Livländische Schulblätter, ı8ı3, I4, 
Póld assumed that Pestalozzi, Ferdinand Kindermann or Bernhard Heinrich Blaschet might have served as examples for him. Epi Tohvri highlights the parallels to the ideas of Pierre-Samuel Du Pont de Nemours on the question of how the school's internal life was organised: those who kept order and looked after others - the 'sergeants' - were to be selected from among the students themselves. ${ }^{36}$ At Kanepi school a so-called headman (Pämees) was appointed who was responsible for maintaining order and keeping the class register; a new headman was appointed every two weeks. The term Industrieschule directly refers to the catholic Bohemian clergyman Ferdinand Kindermann von Schulstein (1740-I80I), who founded the first so-called industrial or vocational school in Kaplice (Ger. Kaplitz) in 1773 , an idea that was widely copied. ${ }^{37}$ Similar initiatives, which not only provided education but also had to help bring relief to the poor and to orphans, were undertaken more widely in Europe, although the term Industrieschule is mainly connected with Kindermann. These ideas reached the Baltic provinces through Germany with the first Industrieschule opened in Göttingen in 1784 . This kind of school also worked in Hamburg from 1788 to $18 \mathrm{II},{ }^{38}$ while the Industrieschule for poverty-stricken girls, which was opened in Lübeck in 1797 , could also have served as a model. ${ }^{39}$

In Courland, Kuldīga (Ger. Goldingen) provost Friedrich Wilhelm Kade (1762-1843) introduced the model of the Industrieschule in order to educate Latvian peasants. In I805, Kade published a brochure, titled Die lettische Industrieschule, that presented the principles and an education programme for both boys and girls that were quite similar to those of Roth's school in Kanepi. ${ }^{40}$ His plan also included a seminar for schoolmasters. Kade dedicated his brochure to count Petr Zavadovskii (I739-I8I2), the first Minister of National Enlightenment

IO5-IO8, I5, II3-II6; [Moritz, F. G.] Erinnerungen an Johann Philipp von Roth. - Magazin für protestantliche Prediger, vorzüglich im Russischen Reiche. J. C. D. Müller, Riga, I8ı8, 225-244; Póld, P. Eesti kooli ajalugu, 67-69; Salupere, M. Meie esimene matsileht, 59I-6oo.

36 Póld, P. Eesti kooli ajalugu, 67; Tohvri, E. Georges Frédéric Parrot, 604-605.

37 Kindermann, F. Nachricht von der Landschule zu Kaplitz in Böhmen. J. F. Edlen von Schönfeld, Prag, I774; Krünitz, J. G. Die Land-Schulen sowohl wie Lehr-als auch Arbeitsoder Industrie-Schulen betrachtet. Buchhandl. des preuß. geh. Commercien-Rathes Pauli, Berlin, 1794, 52I-55I.

38 Trost, F. Die Göttingsche Industrieschule. Heymanns, Berlin, I930; Brandt, M. Die Bestrebungen der Hamburgischen Armenanstalt von 1788 zur Erziehung der Armenbefölkerung. Ein Beitrag zur Geschichte der Industrieschule. Riegel, Hamburg, 1937; Marquardt, W. Geschichte und Strukturanalyse der Industrieschule. Arbeitserziehung, Industrieunterricht, Kinderarbeit in niederen Schulen (ca I770I850/1870). Technische Universität Hannover, Hannover, 1975 (PhD dissertation).

39 Busch, N. Geschichte der Literärisch-praktischen Bürgerverbindung in Riga, 52. See also Heller, L. Geschichte der Lübeckischen Gesellschaft zur Beförderung gemeinnütziger Thätigkeit. Rohden und Bruhn, Lübeck, I839, 104-106.

40 Kade, F. W. Die lettische Industrieschule, in Absicht ihrer Möglichkeit, Nützlichkeit und wesentlichen innern Einrichtung. J. F. Steffenhagen und Sohn. J. F. Steffenhagen und Sohn, Mitau, I805. 
(Министр Народного Просвещения) of Russia. In essence, it was an alternative to Parrot's plan for parochial schools, although neither of the plans were implemented. Kade did not reveal his influences: the Leipzig Charity School (Leipziger Freischule) is mentioned just once (discussed briefly below). Kade's brochure was severely criticised by the lawyer and publicist Friedrich Bernhard Albers, who was upset by the fact that the aim of Kade's Industrieschule was only moral and not aesthetic culture ("Keine ästetische, sondern moralische Kultur") or comprehension culture ("Verstandeskultur"), which would originate from the sphere of activity ("Wirkungskreis") of Latvians. In his opinion, this type of school would pose obstacles to the cultural advancement of Latvians. Albers provoked a moralising debate - based on Immanuel Kant's pedagogical principles, ${ }^{41}$ but the positive results of education and possible practical benefits of the Industrieschule for Latvian peasants were disregarded in this discussion. Albers stifled the debate with a scathing remark on Kade's brochure: "Eine gleich nach der Geburt durch Tod und Verwesung in die ewigkeit übergegangene Broschüre.” ${ }^{2}$ To some extent, the debate also included constructive criticism, ${ }^{43}$ but the discussions did not concern the broader pedagogical concepts of the Industrieschule. Contemporary research generally treats the lettische Industriescbule in the context of the Baltic Enlightenment and the critique of serfdom, but neither traits common to Kade's school plans and Roth's steps, nor connections to Kindermann's Industrieschule, have been noticed. ${ }^{44}$ Roth's and Kade's possible contact during these years has not been researched, although there is no reason to assume that Roth did not know about Kade's brochure. Roth was a member of the Courland Society of Literature and Art (Kurländische Gesellschaft für Literatur und Kunst) founded in I8I7, and his obituary in the periodical of the Society includes quite a detailed overview of the Industrieschule in Kanepi. ${ }^{45}$

4I Immanuel Kant über Pädagogik. Hrsg. von F. T. Rink. F. Nicolovius, Königsberg, I803.

42 Albers, [F. B.] Cultur der Letten - in Kurland. - Der Freimüthige. Dritter Jahrgang, I805, 252, 590-59I; 254, 598-599; [Kade, F. W.] Beleuchtung der Albersschen Kritik [...] einer Schrift, die lettische Industrieschule betitelt, vom Verfasser der genannten Schrift. J. F. Steffenhagen und Sohn, Mitau I806; Albers, F. B. Widerbeleuchtung der angeblichen Beleuchtung einer sogenannten Kritik. J. F. Steffenhagen und Sohn, Mitau I8o6, 3.

$43 \dagger$. Die lettische Industrieschule [...] [recension]. - Wöchentliche Unterhaltungen für Liebhaber deutscher Lektüre in Rußland. Dritter Band, I806, 5, 65-71; 7, 97-I05.

44 Taterka, T. "Für den Geist ist gar nicht gesorgt.” Als Literat in Mitau: Friedrich Bernhard Albers. - Johann Gottfried Herder und die deutschsprachige Literatur seiner Zeit in der baltischen Region. Beiträge der I. Rigaer Fachtagung zur deutschsprachigen Literatur im Baltikum, I4.-17. September 1994. Hrsg. von C. Altmayer, A. Gūtmanis. Latvijas Akadēmiskā bibliotēka, Riga, 1997, 36I-372; Daija, P. Colonial Patterns in Latvian Popular Enlightenment Literature. - Interlitteraria, 2014, 19, 2, 362.

45 [Anon.] Johann Philipp von Roth. - Jahresverhandlungen der kurländischen Gesellschaft für Literatur und Kunst. Bd. 2. J. F. Steffenhagen und Sohn, Mitau, I822, 44-47. 
In July 1807, Parrot, the rector of Tartu University, visited Kanepi parish school and wrote with great enthusiasm about what he had seen there to the emperor Alexander I, describing the school in a longer review as an example worth following:

You should have seen that order, that cleanliness and decency prevailing there [...] The moral, agricultural and technical knowledge they obtained. You should have heard them singing in the church, their folk songs [...]! In those jolly, fearless, smart and clever young people, You would not have seen any signs typical of this humiliated and subjugated folk. Do not fear to give them education, which would not correspond to their future. [...] The most bitter reproach to Latvians and Estonians has been about their laziness, uncleanliness and inebriety. If these schools stay and spread all over the province, in twenty years such sins will disappear almost everywhere, because [by that time] one generation will have enjoyed the fruits of education. This is the benefit You definitely want to see! ${ }^{46}$

Unfortunately, Kanepi school became nothing more than Roth's private initiative, failing to achieve wider results. The obituary, which was probably written by Carl Gottfried Gustav Masing (1789-I859), pastor in Vastseliina, includes a description of Roth's schools: "Although these schools [...] can remain just meteors above our horizon, which die and disappear together with him (which would be unfortunate, though quite likely), they have still existed like beautiful apparitions that Livland could be proud of, the ideal of our rough peasants' potential culture carried into life [...]." ${ }^{\prime 7}$ Malle Salupere regards it as history repeated: "Roth proved with his school what [Bengt Gottfried] Forselius ${ }^{48}$ had once proved to the Swedish king: Estonians are fully capable of obtaining education. His aim was disseminating this education via his students; he even dreamt of founding a seminar for teachers of rural schools." ${ }_{49}$

A longer, colourful description of Roth's schools can be found in the memoirs of Karl Friedrich Burdach, a professor of the University of Tartu. Burdach was in Kanepi in I8I2 or in I8I3. Among other things, he wrote about Roth: "As he could not permanently teach and did not want to hire a teacher, he invented a method of mutual instruction, knowing nothing about Bell and Lancaster, and achieved excellent results, so that everyone admitted to his school was taught by elder schoolmates and they were all working according to the provost's instructions." ${ }^{50}$

46 See Parrot's letter to Alexander I, 8 September 1807, published in: Tohvri, E. Georges Frédéric Parrot, 606.

$47-\mathrm{i}$-. Nekrolog. Johann Philipp von Roth. - Neue Inländische Blätter, I8I8, 3I, 226.

48 See Póldvee, A. Bengt Gottfried Forselius ja rahvahariduse lätted Eesti- ja Liivimaal. (Dissertationes historiae Universitatis Tartuensis, 2o.) Tartu Ülikooli Kirjastus, Tartu, 20 o.

49 Salupere, M. Meie esimene matsileht, 592.

so Burdach, C. F. Blicke ins Leben. Vierter Band, Rückblick auf mein Leben. Selbstbiographie. Leipzig, Leopold Vosz, I848, 237-239. 
It was probably just hindsight that made Burdach connect Roth with Bell's and Lancaster's method, as during his stay in Kanepi the method was not yet relevant in Livland. However, the method of more advanced students helping the schoolmaster to teach beginners was used quite often during the early modern period, for example it was proposed in Methodus Informandi (1683) by Johannes Gezelius, the bishop of Turku. ${ }^{51}$ Forselius, who has been mentioned here several times, was assisted in teaching reading by his teenage schoolboys who had previously received instruction.

\section{OTTO WILHELM MASING AND THE BELL-LANCASTER METHOD}

Otto Wilhelm Masing (1763-I832) is one of the leading figures of Estonian cultural history. His work forms a compulsory part of every general treatment of the Estonian language, journalism, literature or education during the late eighteenth and early nineteenth centuries. Even schoolchildren know that Masing was the man who included the letter of in the Estonian alphabet. However, a comprehensive monograph on Masing is yet to be written. The results of the research by Leo Anvelt (1908-1983), the foremost expert on Masing, can be found in his collection of articles ${ }^{52}$ and in the preface and thorough commentaries on Masing's published letters. Masing's letters to Johann Heinrich Rosenplänter are among the essential primary sources of the present article. ${ }^{53}$ The primers compiled by Masing have thus far been written about in a descriptive manner ${ }^{54}$ or in the context of children's literature and religious pedagogics, ${ }^{55}$ although examples of his teaching method and the provenance of his educational ideas have not yet been thoroughly researched. A couple of brief mentions of the Bell-Lancaster system can be found in earlier literature. Lembit Andresen mentioned that more talented students were told to help those

5I [Gezelius, J.] Methodus informandi in Paedagogiis tam ruralibus qvam urbicis [...]. J. Winter, Aboæ, $1683, \$ 8$.

52 Anvelt, L. O. W. Masing ja kaasaegsed. Lisandusi nende tundmiseks. Eesti Raamat, Tallinn, 1979. About Masing's literary activities, see Vinkel, A. Eesti rahvaraamat, Ioo-I46.

53 Otto Wilhelm Masingu kirjad Johann Heinrich Rosenplänterile 1814-I832 = Die Briefe von Otto Wilhelm Masing an Johann Heinrich Rosenplänter I8I4-I832. I.-4. köide. Personalia. Registrid. Koost L. Anvelt etc. Eesti Kirjandusmuuseum, Tartu, 1995-1997 (further quot. as OWM to JHR).

54 Eesti kooli ajalugu. I. köide, 289-29I, 377-379; Andresen, L. Eesti Aabits reformatsioonist iseseisvusajani. Koolibri, Tallinn, 1993, 48-51, 54-59.

55 Matteus, A. Otto Wilhelm Masing valgustusliku laste- ja noortekirjanikuna. - Keel ja Kirjandus, 2012, 7, 518-536; Matteus, A. Aufklärerische Literatur für estnische Kinder, $30-32$. 
who were weaker. ${ }^{56}$ Leo Anvelt described Masing's wall alphabet book as a totally new study aid in Estonia, and mentioned that Masing used Lancaster and Bell's pedagogical ideas as examples. ${ }^{57}$ Unfortunately, these remarks have deserved no further attention, critical inspection or contextualisation. What did Masing take over from Andrew Bell and Joseph Lancaster, and what other influences did he have? Up to now, no questions have been raised about the possible connections of Masing's primers, teaching methods or orthographic innovations with similar developments in the late seventeenth century.

Otto Wilhelm Masing was born in 1763 in Torma parish, son of a sexton at Lohusuu (Ger. Lohusu) auxiliary church. His father Christian Masick was of Estonian descent, his mother Anna Ludovica von Hildebrandt was German. Masing went to Narva municipal school and Torgau gymnasium, after which he studied theology at Halle University. In the Faculty of Theology at Halle University, rationalist theology prevailed, and Masing's principles were later also based on these concepts; in linguistics, the most outstanding figure was Friedrich August Wolf (I759-I824), professor of philology and rhetoric. Masing helped to proofread Wolf's Greek version of the epics by Homer and for a short time, he taught at the girls' school at Halle orphanage to earn his living. ${ }^{58}$ After graduating, he worked as a tutor in his home country and accompanied the young count Peter August Friedrich von Mannteuffel (1768-1842) on his grand tour of Europe, including Rome. From 1788 to 1795 , Masing was a pastor in Lüganuse (Ger. Luggenhusen) and from 1795 to I8Is in Viru-Nigula (Ger. Maholm). Already in Lüganuse he tried to contribute to the education of the peasants. During his first year of pastorship, he proposed a plan to found a small schoolmasters' seminar in the parish. Unfortunately, only one manor lord in the parish agreed to give him boys (two) to be taught for four years to become schoolmasters. No information is available about the results. ${ }^{59}$ Later, Masing started to seriously consider the idea of founding a schoolmasters' seminar to educate all Estonian peasants. In 1817 , he participated in drawing up a detailed plan for the seminar; the plan was submitted to the commission implementing the

56 Andresen, L. Eesti kooli vanem ajalugu, I4I.

57 Anvelt, L. Masing, Rosenplänter ja nende aeg. - Otto Wilhelm Masingu kirjad Johann Heinrich Rosenplänterile I8I4-I832. Esimene köide I8I4-I8I8. = Anvelt, L. Masing, Rosenplänter und ihre Zeit. - Die Briefe von Otto Wilhelm Masing an Johann Heinrich Rosenplänter I8I4-I832. Erster Band I8I4-I8I8. Koost/Hrsg. von L. Anvelt, E. Aaver, H. Laanekask, A. Nagelmaa. Eesti Kirjandusmuuseum, Tartu, 1995, 26, 43.

58 Tering, A. Eesti-, liivi- ja kuramaalased, 588-589. See also Kingisepp, V.-L. õ-tähe teest meie kirjakeelde. - Emakeele Seltsi aastaraamat, 2016, 62. Teaduste Akadeemia Kirjastus, Tallinn, $2017,287$.

59 Anvelt, L. O. W. Masing Lüganusel. - Anvelt, L. O. W. Masing ja kaasaegsed, 4I-42. 
Peasantry Law in Estland. Berend Johann von Uexküll, chairman of the commission and Governor of Estland province from 1808 to I8I9, submitted the plan, which included Masing as director of the seminar, but neither the government nor the Estland Knighthood were ready to cover the costs of the seminar. ${ }^{60}$

Masing compiled his first Estonian primer already at Lüganuse, its didactic introduction bears the date of $\mathrm{I} 4 \mathrm{July}$ 1794, and it was published in $1795 .{ }^{61}$ Unlike earlier Estonian primers, where the reading section consisted only of the catechism, Masing's primer also included secular texts for reading. This is famously also the first primer in Estonian, ${ }^{62}$ which gives general pedagogical advice in a ten-page introduction under the heading "Dear Parents" (Armad Lapsewannemad) and emphasises the joy of learning, the need to avoid coercion and punishment, and the need to set feasible progress goals. The title page of the primer also demonstrates learning at home under mother and father's guidance (see Figures I-2). The instruction for learning to read is based on the typical spelling method. At first, letters are learnt - one or two letters per day, in random order, so that pupils would not learn the alphabet by heart before they learn separate letters. After that, they learn syllables and how to spell out words syllable by syllable. Finally, reading should sound like natural speech, not an "untowardly and nasty twang". Therefore, punctuation marks have to be learnt, which Masing explains on more than four pages. In the final part, the primer gives instructions on how to count $(\mathrm{I}-9,000)$ and to use the multiplication table. In several aspects, Masing's primer is considered similar to the picture primer Bildu-Abbize (1787) by Gotthard Friedrich Stender (1714-1796), a pastor in Courland. ${ }^{63}$ The fact that Stender's primer demonstrated pictures and double verses together with letters reveals a tendency to move towards the phonic method, but in all other aspects it was based on the spelling method with traditional names of letters ( $k a, e l$, em, etc.). ${ }^{64}$ Illustrations on the title

6o Anvelt, L. Masing, Rosenplänter ja nende aeg, 29.

6I [Masing, O. W.] ABD ehk Luggemise-Ramat Lastele kes tahawad luggema öppida. M. G. Grensius, Tarto, 1795 .

62 The first print of B. G. Forselius' primer, which has not been preserved, also included a preface. Here, Forselius most probably explained its innovative orthography and pronunciation rules.

63 [Stender, G. F.] Bildu-Ahbize. J. W. Steffenhagen, Jelgawâ, I787; [Apīnis, A., Klekere, I., Grudule, M., Villerušs, V.] Gotharda Frīdriha Stendera ābeces. Faksimili. Transkripcijas. Apceres. Neptuns, Riga, 2014.

64 Balode, I. Der Beitrag Gotthard Friedrich Stenders (1714-1796) zur Alphabetisierung der lettischen Bauern. - Sprachmeister: Sozial- und Kulturgeschichte eines prekären Berufsstands. Hrsg. von M. Häberlein. (Schriften der Matthias-Kramer-Gesellschaft zur Erforschung der Geschichte des Fremdsprachenerwerbs und der Mehrsprachigkeit, I.) University of Bamberg Press, Nürnberg, 2015, I03-I32; Balode, I. Gotharda Frīdriha Stendera ieguldījums latviešu alfabetizācijā. - Gothards Frīdrihs Stenders (I7I4-I796) un 
pages of both primers are remarkably similar: on both primers, home tuition is depicted (see Figures I-2), in Stender's primer, there are verses under the picture: "Sohds mahtei, kas to mihti darr, / Ko tehws dehl darbeem tà ne warr" (Respect mothers, who lovingly perform the tasks, which fathers cannot perform due to their work).
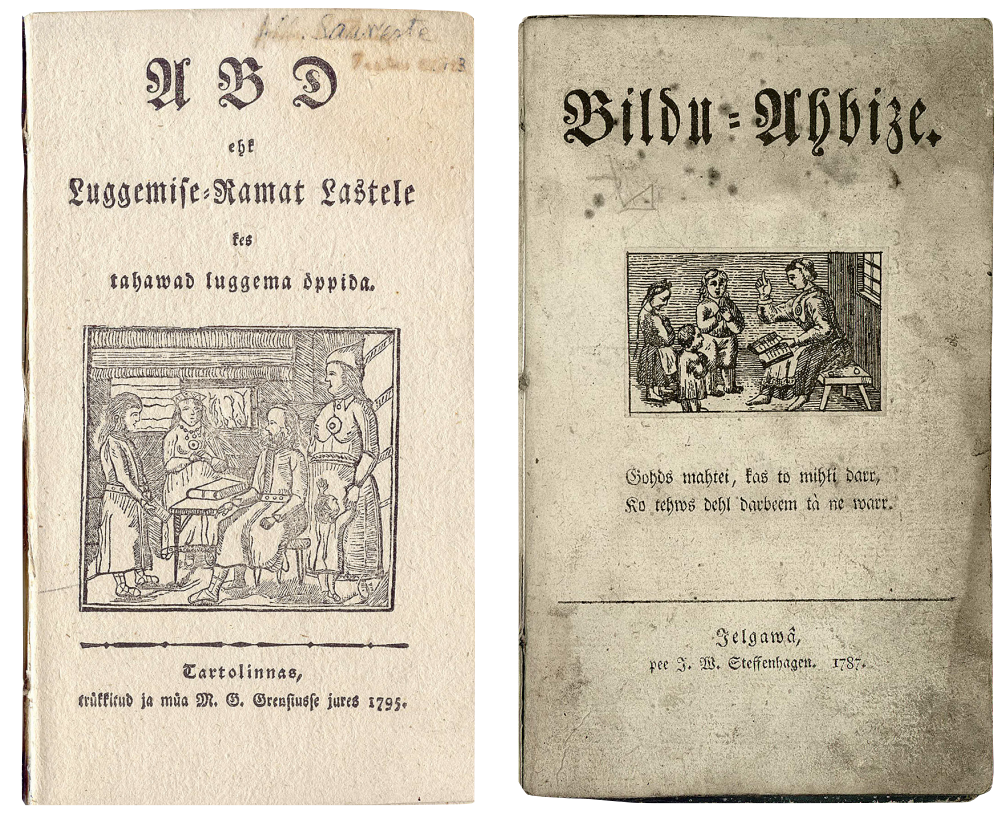

Figures I-2. Title pages of the primers by O. W. Masing (I795) and G. F. Stender (I787). Both pictures demonstrate learning at home under mother or father's guidance.

The Estonian language in Masing's primer was perceived differently. According to J. H. Rosenplänter, this book, unlike translations, which were full of Germanisms, made Estonians accept that "this is my language". ${ }^{65}$ Peter Koch, a pastor at Jôhvi (Ger. Jewe), was more critical, drawing Masing's attention to linguistic errors in his primer and suggesting not to rush to act like a man of letters. Koch was an authority figure for Masing and thus Masing became very critical of his primer, even burning the roughly 300 unsold copies of the print run. In addition, he gave up writing texts in Estonian for a long time. ${ }^{66}$

apgaismība Baltijā Eiropas kontekstā: kolektīvā monogrāfija = Gotthard Friedrich Stender (I7I4-I796) und die Aufklärung im Baltikum im europäischen Kontext $=$ Gotthard

Friedrich Stender (1714-1796) and the Enlightenment in the Baltics in European Contexts. Sast. un zinātn. red. M. Grudule. LU Literatūras, folkloras un mākslas institūts, [Riga], 2018, 246-264.

65 Beiträge zur genauern Kenntniss der esthnischen Sprache. Hrsg. von J. H. Rosenplänter, $1813,2,25$.

66 Anvelt, L. O. W. Masing Lüganusel, 42-43. 
It was only in 1816 that Masing, already as pastor in Äksi (Ger. Ecks), published the book Ehstnische Originalblätter für Deutsche, introducing perspectives of a peasant's language as a written language and explaining how necessary it was for Germans who had contacts with Estonians to learn their language. Masing's next book, Pühhapäwa Wabhe-luggemissed (Selected Pieces of Reading for Sundays), published in 1818, was a popular science storybook for Estonians. Masing's reputation as an Estonian linguist grew year by year, as did the number of books he had published in Estonian. Beginning in I819, he published the newspaper Marabwa Näddala-Leht (Peasants' Weekly) to enlighten people, with a run of four years (182I-1823 and I825) and 1,668 pages all together. ${ }^{67}$ From I819 Masing translated official announcements and legal acts of the Governorate of Livland and was entrusted with translation of the Peasantry Law of Livland. ${ }^{68}$

The 1819 Peasantry Law abolished serfdom in Livland province, while serfdom had been abolished in Estland province three years earlier. Founding and managing schools now became the task of manor communities i.e. rural municipalities. In Estland, one school per I,ooo inhabitants had to be founded; in Livland, there had to be a school in every rural municipality with at least 500 men. In Livland, apart from rural municipality schools, there were also the second level parochial schools, which had a more comprehensive curriculum. ${ }^{69}$ The optimism that followed the peasants' emancipation and new prospects of enlightenment made Masing devote more attention to promoting the Estonian language and education, and encouraged him to cherish higher hopes. Correcting written language went hand in hand with drawing up learning materials. These tasks complemented each other and involved the single aim of learning to read becoming more efficient and taking less time and fewer material resources. The first measure was natural and phonetically correct writing. The second direction was applying what modern foreign methods could be to Estonian circumstances.

The idea that the learning process had to become quicker, more rational and cheaper, is connected to the burgeoning industrialism, which heightened the need to educate and discipline large numbers of children from poor families. This gave rise to the approach that a school should

67 See Peegel, J., Aru, K., Issakov, S., Jansen, E., Lauk, E. Eesti ajakirjanduse teed ja ristteed. Eesti ajakirjanduse arengust (XVII sajandist XX sajandini). Tartu Ülikool, Tartu, [Olion,] Tallinn, 1994, 64-8I. See also Kingisepp, V.-L. Otto Wilhelm Masingu "Marahwa NäddalaLehhe" sõnastik. Tartu Ülikooli kirjastus, Tartu, 2020.

68 Liwlandi-Ma Tallorahwa Seädus. Essimenne-Kolmas jaggu. [Trans. by O. W. Masing.] J. C. Schünmann, Tarto, I820. About schools see: \$516-517, I48-156.

69 Eesti kooli ajalugu. I. kd, 347-350. 
be organised like a factory and learning aids should be like machines. Useful machines and various technical innovations were very characteristic of the intellectuals of the Enlightenment age, the most widely known example being Benjamin Franklin's lightning rod or the washing machine of G. F. Stender, mentioned above. ${ }^{70}$ The Bell-Lancaster system was the most consistent and widely spread continuation of this trend in pedagogics. The system itself was developed by Andrew Bell (1753-1832), a Scottish clergyman in British India, and Joseph Lancaster (I778-1838), a Quaker in England, independently of each other. In 1789 , Bell founded a school at a military poorhouse in Egmore near Madras. Lancaster started with his method at a school opened in I8or in Southwark, London. The system according to which more advanced students acted as assistant teachers ('monitors', as Lancaster called them) together with the main teacher, is known as to the method of mutual instruction. Hundreds of students were taught simultaneously in the same room; groups of students moved from one place to another and learned under the guidance of their monitors from posters hanging on the walls. Beginners learned by writing letters in sand, thus helping to minimise costs. The whole teaching process, as well as the design of the schoolhouse and equipment were very strictly rationed and calculated. The principle - one teacher to a thousand students - worked like a slogan. ${ }^{71}$ Bell described the main idea of this mechanical system in a very straightforward way: "The schoolmaster, whose province it is to watch over and to conduct this machine in all its parts and operations [...]." ${ }^{2}$

The Bell-Lancaster system soon attracted considerable interest all over Europe as well as in the USA and elsewhere. Bell and Lancaster stimulated the interest with books introducing their method as a British education project. Russia had in 1807 considered the idea of applying the English system in the Baltic provinces instead of founding rural municipality schools. ${ }^{73}$ Detailed information about the new method was disseminated in Russia by Joseph Christian Hamel (1788-1862), who at the initiative of the Minister of the Interior and on the mission

70 Stender, G. F. Beschreibung einer neuen höchst bequemen Washmaschine. Kanter, Mitau, 1765 .

7I Stratenwerth, W. Ein Lehrer und tausend Schüler. Joseph Hamels Dokumentation über den gegenseitigen Unterricht (Paris I8I8). Eine Neuausgabe des von Zar Alexander I. in Auftrag gegebenen Werkes, verbunden mit einer Einführung in das Bell-Lancaster System, einer ausführlichen Biografie Hamels sowie einer systematischen Darstellung der russischen Lancasterschulbewegung. 2. aktualisierte, ergänzte und korrigierte Auflage. Edition Winterwork, Borsdorf, 202O, 14-42.

72 Bell, A. The Madras School, or Elements of Tuition: comprising the Analysis of an Experiment in Education, made at the Male Asylum, Madras [...]. T. Bensley, London, I808, 26-27 (my emphasis).

73 Tohvri, E. Georges Frédéric Parrot, 663. 
of the emperor Alexander I travelled to England in 1813 to gather information about Bell-Lancaster schools. Hamel's detailed description was published in German in I8I8 and two years later in Russian. ${ }^{74}$ This was probably also the book that was sent by Karl Christoph von Lieven, the curator of the Tartu school district, to the director of Tartu Governorate Gymnasium in I819. ${ }^{75}$ Emperor Alexander I personally examined the Bell-Lancaster system while visiting London in I8I4. Officers of the Russian army of occupation learned about the Lancaster-type schools in Paris, where the method was used to teach Russian soldiers. In I8I7, the first Bell-Lancaster schools were opened in Russia for children of the emperor's guards, and within ten years the number of schools of this type for children of military personnel and people in poverty exceeded $200 .^{76}$

This kind of background quite clearly explains Masing's interest in the Bell-Lancaster teaching method. Masing's textbook Luggemisse lebed (Reading Sheets) was in principle a primer, the contents of which had been laid out on 38 separate sheets - capital letters in Gothic script on full sheets, other material in 32 tables in folio format. Alphabet, syllables, syllabised practice words and sentences from the scripture were followed by punctuation marks, numbers and lower-case letters. One hundred separate letters and 40 numbers printed on cardboard cards had to be bought separately. ${ }^{77}$ The manuscript of the book was approved by the university's censorship committee on 22 January I82I. Masing drew up methodological instructions on how to use the reading sheets, and these were published separately. ${ }^{78}$ The instructions also indicate Masing's sources of inspiration. Both Bell and Lancaster have been referred to, but without mentioning their names. Masing admires the clever Indian people, who take "very good care” of their children's education. From "time immemorial", Indian children have been taught to write in the following way: huge sheets with examples of letters are hung on walls, children sit at a table, small sharpened wooden sticks in hand; sand or ashes are sieved on the table and this is where they write letters. Advanced

74 Hamel, J. Der gegenseitige Unterricht; Geschichte seiner Einführung und Ausbreitung durch Dr. A. Bell, L. Lancaster und andere; Ausführliche Beschreibung seiner Anwendung in den englischen und französischen Elementarschulen, so wie auch in einigen höheren Lehranstalten [...]. Bey Firmin Didot, Paris, I818.

75 Tohvri, E. Georges Frédéric Parrot, 664.

76 Орлов А. А. Ланкастерские школы в России в начале XIX в. - Педагогика и психология образования, 2013, I-2, II-20, 9-23; Zacek, J. C. The Lancastrian School Movement in Russia. - The Slavonic and East European Review, 1967, 45, 343-367; Tohvri, E. Georges Frédéric Parrot, 64-65.

77 Masing, O. W. Luggemisse lehhed, mis Otto Willem Masing wäljaandnud. [J. C. Schünmann,] Tartu, I82I.

78 Masing, O. W. Ôppetus kuida neid luggemise lehti kassuga prukida mis Otto Willem Masing wäljaandnud. [J. C.] Schünmann, Tartu, I82I. (The date provided by Masing: 9 January I82I). 
pupils write on stone slates and finally also with ink on paper. Masing added that quite recently, some clever Englishmen living in India (i.e. Bell) decided to teach their children in the same way and started to use this method in England (i.e. Lancaster). The gracious Russian emperor, who carefully considers all that might benefit his subordinates, has decided to teach writing to his soldiers' children accordingly, and already for the second year running. Masing had seen it in the autumn of the previous year (i.e. 1820) in Riga, where more than 500 boys and young men were learning writing in a soldiers' school. Therefore, examples of lower-case letters had been added to the reading sheets, so that some wise schoolmasters might use the examples of the Indian people to teach writing. ${ }^{79}$

Information about the idea and use of the reading sheets can be found in the correspondence between Masing and Rosenplänter. Johann Heinrich Rosenplänter (1782-1846) was a pastor of the Elizabeth congregation in Pärnu (Ger. Pernau) in Livland from I809, and as an Estophile published the journal Beiträge zur genauern Kenntniß der ebstnischen Sprache (1813-1832) at his own cost. Masing became a permanent contributor to Rosenplänter's journal and their mutual interest in the Estonian language and the school became the basis of their longstanding relationship and good cooperation. Rosenplänter also regarded Lancaster's method as a possible way to teach. In March I820, he started a fundraising campaign to found a Lancaster school for Estonian youth in Pärnu. At that time, Estonian children had no vernacular school and thus studied at a German school, but not with the desired results. Two years later it became clear that the funds raised were not sufficient, and Rosenplänter agreed with the donors that a less costly school should be opened, which would work according to provost "Masing's method". As this was unfeasible without the support of the city, Rosenplänter asked the magistrate to give them a classroom and pay the future teachers' salary. In December I822, Rosenplänter repeated his application, but received no support. ${ }^{80}$ Rosenplänter's letters to Livland Superintendent General Sonntag reveal that he had already introduced Masing's method to the rural schoolmasters of his parish in the autumn of $1821 .{ }^{81}$

79 Masing, O. W. Óppetus kuida neid luggemise lehti kassuga prukida, I8-20.

80 Anvelt, L. Lisandusi J. H. Rosenplänteri tundmiseks. - Anvelt, L. O. W. Masing ja kaasaegsed, 20;; Paatsi, V. Täiendusi Johann Heinrich Rosenplänteri eluloole. - Paatsi, V. Rännates Gutenbergi galaktikas. Kultuuriloolisi uurimusi aastatest 1993-20I5. Koost ja toim K. Metste. Ilmamaa, [Tartu], 2016, 236-237.

8I J. H. Rosenplänter to K. G. Sonntag (26 October I82I). Estonian Literary Museum (Tartu), EKLA, Koopiad, M 88:I, 1. 95. 


\section{MASING'S METHOD}

Masing's letters to Rosenplänter demonstrate in great detail how his reading sheets were born and what the difference was between his method and Lancaster's system. When Masing stayed in Riga dealing with church matters in September 1820 and visited a Lancaster-type school, he had already started preparing his reading sheets. He ordered wooden print types (Holz Lettern) from Riga and spoke highly of them to Rosenplänter. In the same letter, he described his learning aid to his colleague, promising that his reading panels, i.e. posters (Lesetafeln), would offer major benefits to rural schools: "Once they have been received and covered with good varnish, young people need no more primers at schools. - A lazy schoolmaster has to work harder and all those present will be taught together; at the same time, children can be instructed how to teach the younger ones, show them letters and make them spell. With moving letters [i.e. printed alphabet tiles], children can construct any words they are told, they can add letters at the beginning or end of the word or take them away, so that they can learn various ways and are prepared to write correctly." 82

When Masing got back from Riga, it appeared that the reading posters, if glued on cardboard and covered with varnish, would be too expensive and that 300 copies would take too much storage space. Masing decided to delegate the task of gluing the printed reading posters and supplying them with frames to schools. After that, he found another technical solution: instead of small nails and loops to hold the movable numbers and letters, it was more convenient to use only small slats, onto which the numbers and letters could be placed..$^{83}$ Masing suffered several setbacks when preparing his reading posters. As his orthography innovations were met with resistance among some intellectual circles, Masing complained to Rosenplänter that together with the reading posters, he would stop all the "damned Estonian writing business" (verwünschte ebstnische Schriftstellerei) and everything even remotely connected with the Estonian language. ${ }^{84}$ In December 1820 , when Masing presented his reading posters to the censorship committee in Tartu before printing them, he was informed that according to the emperor's orders, only reading posters in Russian issued by the ministry of education were allowed in schools, i.e. everything else was officially forbidden. Masing

82 OWM to JHR, II/Io3 (24 September 1820).

83 OWM to JHR, II/Io6, II/IIo (9 October I820; 6 November I820).

84 OWM to JHR, II/Io8 (26 October I820). 
first suspected that the ban for his reading posters was initiated by his opponents, who were against his orthography innovations. When things were clarified, an opportunity was found to ignore the ban: the reading posters were renamed and became reading sheets. ${ }^{85}$

On 23 February I821, Masing described his reading sheets in his weekly in an article entitled "About Matters of Writing and Teaching" (Kirja ja ôppetuse asjust). To introduce the topic, Masing says that Estonian orthography is still "confusing and incomplete". There is a longer explanation about the reading sheets, ending with an optimistic opinion that with these letters, a wise and conscientious schoolmaster will be able to teach his pupils to read in two or three months. ${ }^{86}$ On 7 March I82I, the reading sheets went into print, and on the following day Masing sent 30 promotional leaflets to Rosenplänter with the headline "For Information" (Teäduseks) to be distributed in Pärnu and Saaremaa (Ger. Ösel) counties. ${ }^{87}$ Masing explained: "The promoted abd-sheets - whatever they are called - should be used like Lancaster's reading posters - You understand me and I do not need to clarify. I can print only movable letters on cardboard and nothing else, otherwise they would be posters oh yes! jam satis! [Lat. that's enough].” Masing hoped that he had done a good deed for the future with his reading sheets, and commended the alphabet of lower-case letters (see Figure 3) that had been printed: "It is nice to look at, only the unpronounced e accompanying the consonants (stumme e) stands a bit too far." ${ }^{88}$ The "unpronounced e", however, is the key to understanding the phonetic aspects of Masing's method, and will be discussed below. On 20 September I82I, before the schoolyear began, Masing drew up a leaflet (Anzeige) to introduce his reading sheets, including the price of the set -2 roubles and 50 kopecks. ${ }^{89}$

On I November I82I, a reading school was opened in Äksi and lessons held during the confirmation. Out of its 3I students, only one was younger than seventeen. Masing taught the students twice a day, one lesson before lunchbreak and one after; he was assisted by a sexton and a recently hired schoolmaster from a rural municipality school. After the third school day, Masing wrote to Rosenplänter saying that he could see a miracle happening and that he was convinced that the reading sheets

85 OWM to JHR, II/II6 (24 December 1820). Even later, Masing was ironic about the censorship, mentioning "my reading posters" in a letter to Rosenplänter, and adding: "I am to be punished when I say: 'My Abc-sheets'." "'Doch ich sprech strafbar, meine AbcBlätter”). OWM to JHR, III/I23 (8 March I82I).

86 Marahwa Näddala-Leht, 8 February i821, 8, 59-6o.

87 Masing, [O. W.] Teäduseks. [I82I] Estonian Literary Museum (Tartu), KMAR Eıı.

88 OWM to JHR, III/I2o.

89 Masing, O. W. Anzeige, 20 September I82I, Estonian Literary Museum (Tartu), KMAR OEES 325 . The price of the set is equal to about a tchetwert [ca 20 litres] of rye. 


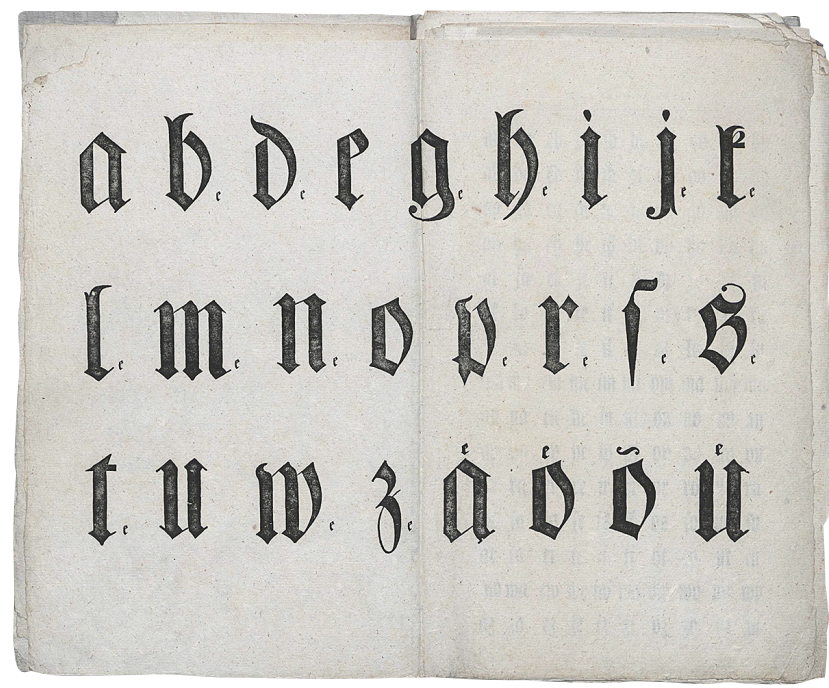

Figure 3. The lower-case alphabet (consonants with unpronounced e) from O. W. Masing's reading sheets (I82I).

were a success. The reading cards make even the most phlegmatic ones think, because the students like the idea that they are producing something. Masing emphasised: "My method is not Lancaster's method, but my own; even if the two systems sometimes overlap, it only means that both of us have independently reached the same conclusions, and this also proves that this is a natural learning method." Masing confirmed that the work was quick and thorough, and he hoped that more than half of the students would be able to read quite well in three weeks. ${ }^{90}$

Although Masing pointed out that his learning method was natural and original, Lancaster's and Bell's ideas and examples had undoubtedly inspired him. The reading sheets' instruction mentions India and England (see above) and suggests a teacher could use smarter students to teach those lagging behind. ${ }^{91}$ However, it is quite evident that in sparsely populated Estland and Livland, the conditions for the new type of school were different from densely populated India, industrialising England or the Russian military. At Masing's own school, where three people were teaching, there was no need for mutual instruction, at least in the beginning. Masing's reading sheets did not circulate as widely as their author had hoped, and the fact that there were unsold reading sheets worth a substantial amount of money $(\mathrm{I}, 300$ roubles in March 1822) also caused problems. Only three sets had been ordered for the Governorate of Estland. ${ }^{92}$ At the same time, the Consistory of 
Estland was planning to publish their own reading posters. Already at the beginning of I821, Christoph Adam von Stackelberg, a school director of a governorate school, had asked the consistory for support publishing a learning aid that would be based on Pestalozzi's as well as Lancaster's and Bell's methods. ${ }^{93}$ As this plan was not carried out, it's difficult to say anything about the circumstances of this learning aid, which might have been the reading posters that P. A. F. Glanström, a pastor at Ambla (Ger. Ampel), drew up and used at the school that had opened in his pastorate. In 1822, Glanström informed the Consistory of Estland in a memorandum, that children learned to read with his reading sheets in three months and many of them also learned to write. The opinion expressed by O. R. von Holtz, a pastor at Keila (Ger. Kegel) and a member of the consistory and school committee, that such reading posters should be used by travelling schoolmasters, indicates how the local situation differed from a school system in which one teacher teaches a thousand students. ${ }^{94}$ In Estland, the use of travelling schoolmasters was justified by the English example. At the end of 1822, Masing published in his newspaper a critical comment to the proposal that every parish should have two to four schoolmasters travelling from village to village, each of them having "a primer in his bosom". ${ }^{95}$

\section{MASING AND THE PHONIC METHOD}

For Masing's teaching method, correct Estonian language and orthography corresponding as exactly as possible to the real pronunciation was as important as the innovative design of his primer, i.e. posters and printed alphabet tiles. Masing added the letter ô to the Estonian alphabet and suggested marking palatalisation and distinguishing between short and long consonants. ${ }^{96}$ At that time, double consonants were used to mark the preceding short vowel, but this led to misunderstandings. Masing proposed his ideas in a brochure entitled Vorschläge zur Verbesserung der Ebstnischen Schrift (1820). ${ }^{97}$ To promote his innovations, he ordered printing moulds of diacritical signs, which were used neither in

93 Records of the Estland Consistory, 26 January I82I. National Archives (Tartu), EAA $1187.2 .126,67$.

94 Speer, H. Das Bauernschulwesen im Gouvernement Estland, I07-I09; OWM to JHR, III/135, III/167 (8 October I82I; 3 August I822).

95 -sb-. Üks kirri Tállina-maalt [...]. - Marahwa Näddala-Leht, I3.12.1822, 50, 394-395.

96 Kask, A. Eesti kirjakeele ajaloost I. Tartu Riiklik Ülikool, Tartu, I970, II3-II6.

97 [Masing, O. W.] Vorschläge zur Verbesserung der Ehstnischen Schrift. J. E. Schünmann, Dorpat, 1820 . 
the German alphabet nor in the Schünmann printing house in Tartu, all at his own cost. In addition to the letter ô, Masing used points under his vowels and stress marks, and in the brochure mentioned above also crossed-out consonants (according to the examples of Latvian orthography), which he later omitted. Palatalisation and stress marks were used on his reading sheets and also in his primer Täieline ABD-ramat (A Full ABD-Book, 1823 ), which was based on the reading sheets. ${ }^{98}$

Apart from the added printing costs, the renewed writing style provoked colleagues' criticism, which Masing managed to counter with his ample practical experience. In November 1821, when the school year in Äksi had just begun, he mentioned to Rosenplänter that pastors were complaining about the renamed letters and new characters ("Umbenahmung der Buchstaben, und über die neue Schriftzeichen”), which people were reported to be unable to understand. Masing confirmed that he could teach the new characters to even the smallest children in a quarter of an hour and that they made reading easier. ${ }^{99}$ The instruction of the reading sheets suggested attracting students' attention with chain reading, so that they could compete in reading with the greatest pleasure and joy. For example, in the word arm (grace, scar), Mart should say a-, Hans $r$-, and Peter $m$. To read the word armastus (love), Mart should say ar, Hans mas, Peter tus, and Karel armastus.

Masing's views and activities in the field of Estonian orthography, lexicography and common written language have been quite widely researched. Heli Laanekask has tried to place Masing's innovations into the wider linguistic context of the eighteenth and nineteenth centuries. ${ }^{100}$ Yet the linguistic background of his method of teaching reading is still missing. The fact that he changed the names of letters has received no mention - neither linguists nor educationalists have noticed it, although this is the key element of both Masing's reading sheets and his primer of I823. The consonants with small e are clearly visible (see Figure 3). Masing emphasises separately that the letter $\mathrm{h}$ should be pronounced with aspiration hee. Most probably this has remained unnoticed just because Masing himself used the word 'spell' to explain his method. Thus, the relevant chapter in his teaching manual bears the title "About Spelling" (Werimisest). What he really had in mind was smooth reading

98 Masing, O. W. Täieline ABD-ramat, kust makele luggemist ôiete ôppida.

[J. E.] Schünmann, Tartu, I823.

99 OWM to JHR, III/138 (tpq 3 November I82I).

Ioo Laanekask, H. O. W. Masingu keeleteaduslikust vaatepiirist. - Keel ja Kirjandus, I982, 3, I22-I33. 
of syllables (poled sõnnad) pronounced correctly with the help of the new names of the letters, ${ }^{101}$ i.e. a combination of sound and syllable methods.

The sole purpose of the new letters and new letter names was to create an orthography that would correspond as closely as possible to the pronunciation and thus make it easier to learn to read using the phonic method. Debates had been held and proposals made regarding this question in sixteenth and seventeenth century Germany, England, France and other countries, reaching Estonia at the end of the seventeenth century. ${ }^{102}$ As early as the mid-I68os, Bengt Gottfried Forselius started using the optimised alphabet and new consonant names ke, le, me, ne, re, se, etc., in his innovative primer. In 1693, Johann Hornung's Grammatica Esthonica, in which consonants bear the same names (see Figure 4), made the orthography reform official but only in Livland. ${ }^{103}$ How did Masing arrive at the same solution? Did he follow the old tradition or did he start anew after a break in the tradition?

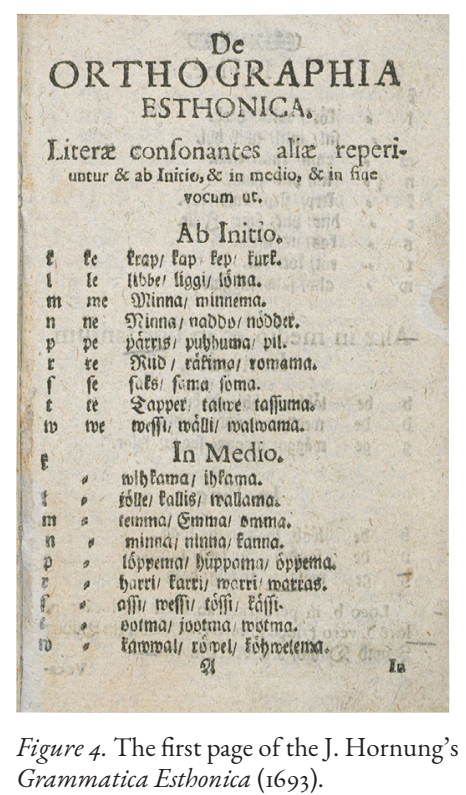

Forselius' and Hornung's names never come up in Masing's surviving letters or texts. In the nineteenth century, Hornung's Grammatica Esthonica was already such a rarity that Rosenplänter, who tried to set up a library of Estonian-language books (Bibliotheca estonica) and make it as complete as possible, had only a re-written copy of it. In Rosenplänter's

IOI Masing, O. W. Ôppetus kuida neid luggemise lehti kassuga prukida, 4, 8-I3.

IO2 See Pôldvee, A. 17th Century Estonian Orthography Reform.

I03 Hornung, J. Grammatica Esthonica, brevi. Perspicuâ tamen methodo ad Dialectum Revaliensem. J. G. Wilcken, Riga, [1693]. 
collection, the oldest Estonian ABC book was Masing's primer of $1795 .{ }^{104}$ Today, all copies of Forselius' known primers are held in foreign libraries, the latest reprint dating from I74I. ${ }^{105}$ Masing's primer of 1795 reveals no signs of Forselius' method of learning. The possibility that, unlike in Lüganuse parish Forselius' letter names were still in use in Äksi and Masing heard them from local folks, cannot be fully excluded. However, the fact that the consonant names with stumme $e$ on his reading sheets were novel and disturbing to Masing's pastor colleagues indicates rather a break in the tradition. Or maybe it was broken just at some locations? In major European languages, the question of the phonetic orthography and teaching method has repeatedly come up throughout the centuries, so that new ideas were actually old ideas long forgotten. For example, Benjamin Franklin's changes of alphabet and phonetic orthography

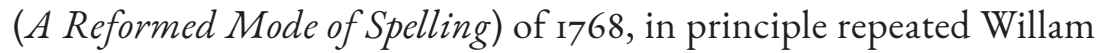
Bullokar's proposals of $1580 .{ }^{106}$

Although Lancaster schools in England used monitors, sand tables, posters, etc., and the process of learning was divided in to eight to ten classes, their method of teaching reading was the traditional spelling method, i.e. naming letters and reading words out syllable by syllable. At the same time, students learned how to write letters. Before this, learning to read and write had taken years, now it took just some months with the new system, and more talented students completed the full course in a year. ${ }^{107}$

Masing used elements of the Lancaster system, but instead of the drill, discipline and mechanical repetition, his main focus was on linguistics that had been characteristic of supporters of the phonic method throughout ages. In Germany, this tradition goes back to the school innovations of the Reformation during the sixteenth century, but the level of Valentin Ickelsamer's phonic method could be repeated only in

IO4 [Rosenplänter, J. H.] Uebersicht der esthnischen Litertur, nach dem Inhalte der Schriften und chronologisch geordnet. - Beiträge zur genauern Kenntniß der esthnischen Sprache. Zwansigstes Heft. Pernau, beim Herausgeber, Reval, bei Bornwasser, I9, 24.

Ios Póldvee, A. Viis aabitsat ja Forseliuse ôppeviis, II4-II9.

Io6 Bullokar, W. Booke at large, for the Amendment of Orthographie for English Speech. Henrie Denham, London, I580; Franklin, B. A Reformed Mode of Spelling. - Franklin, B. Political, Miscellaneous, and Philosophical Pieces [...]. J. Johnson [...], London, I779, 467-478; Webster, N. Dissertations on the English language: with notes, historical and criticito which is added, by way of appendix, an essay on a reformed mode of spelling, with Dr. Franklin's arguments on that subject. I. Thomas and Company, Boston, 1789.

Io7 See a thorough description by J. Hamel: Stratenwerth, W. Ein Lehrer und tausend Schüler, II2-I2O; Lancaster, J. Improvments in Education [...]. Third Edition. Darton and Harvey, London, I805; Manual of the System of Teaching Reading, Writing, Arithmetics, and Needle-Work, in the Elementary School of the British and Foreign School Society. First American Edition. Philadelphia, B. Warner, I817, I4-22. 
the nineteenth century. ${ }^{108}$ Only Heinrich Stephani (I76I-I850) offered a more convincing criticism of the spelling method and a justification of the phonic method that derived from the recognition that a letter, a sound and the name of the letter (Buchstabe, Buchstabenlaut, Buchstabenname) are all different things. In I802, Stephani published an innovative primer that was supplemented by a wall primer (Wand-Fibel) of twelve posters adapted to the phonic system. ${ }^{109}$ At Stephani's initiative, the spelling method was given up in Bavaria in 1803 , although in Prussia the same decision was reached only in 1872 . Stephani gave very clear instructions to the mothers who were teaching reading at home on how to avoid mistakes caused by the spelling method: children should not be told anything about the names of letters before they have learned to read, they had only to articulate letters. ${ }^{110}$

Masing's method was not directly influenced by Stephani. Instead, his new consonant names and syllabised texts seem to have followed the models of the pedagogues at Dessau. Johann Bernhard Basedow (1724-1790), founder of the Philanthropinum, published a textbook called Elementarwerk (1774) that suggests pronouncing consonants (Lippenbuchstaben, Zungenbuchstaben, Keblbuchstaben) me, be, se, we, etc., so that the $e$ would be quite quiet (etwas leise). ${ }^{111}$ This is also the proposal of Ludwig Heinrich Ferdinand Olivier (1759-1815), who elaborated the phonic method and was a teacher at Dessau Philanthropinum in the I78os. Olivier specifies that the natural auxiliary sound or schwa ("der natürliche Hülfslaut oder Schwa") would help to pronounce and read consonants. ${ }^{112}$ Olivier understood the general potential of the phonic method and dedicated his Orto-epo-graphisches Elementarwerk (1804) to the Russian emperor Alexander I.

Masing mentioned neither Stephani, Basedow nor Oliver, but there is no reason to think that their ideas or teaching methods were unknown to him. At the beginning of the nineteenth century, these topics were quite vividly discussed in the German press, and new learning

Io8 Pohl, K. Ickelsamers Beitrag zur Begründung des Erstleseunterrichts. - Valentin Ickelsamer. Die rechte weis auf kürtzist lesen zu lernen. Ain Teütsche Grammatica. Hrsg. von K. Pohl. Klett, Stuttgart, I97I, VIII.

Io9 Stephani, H. Handfibel oder Elementarbuch zum Lesenlernen nach der Lautiermethode. Palm, Erlangen, I802; Stephani, H. Kurzer Unterricht in der gründlichsten und leichtesten Methode Kindern das Lesen zu lehren. Palm, Erlangen, I803; Stephani, H. Ausführliche Beschreibung der genetischen Schreibmethode für Volksschulen. Palm, Erlangen, I8I4.

IIo Stephani, H. Fibel für Kinder edler Erziehung; nebst einer genauer Beschreibung meiner Methode für Mutter [...]. Palm, Erlangen, I806, 2I.

III [Basedow, J. B.] Des Elementarwerks Erster Band [...]. Bey S. L. Crusius in Leipzig, auch bey dem Verfasser und seinen Freunden, Dessau, 1774, 22-33.

II2 Olivier, F. Orto-epo-graphisches Elementarwerk; oder: Lehrbuch über die in jeder Sprache anwendbare Kunst rechtsprechen, lesen und rechtschreiben zu lehren. Erster theoretischer Theil. Dessau, Schul-Buchhandlung, 1804, 47. 
aids including printed posters and alphabet tiles were widely used. These innovations are reflected in Friedrich Wilhelm Kade's aforementioned Die lettische Industrieschule (1805). Kade suggested thinking about an elaborated method ("eine verbesserte Methode"). He had heard about Latvians who had learned to read in eight weeks just because vowels and diphthongs (Doppellauter) had been practiced before the main tones of all languages (Grundtöne aller Sprache), and consonants were practiced without naming their names and only together with vowels and diphthongs. Instead of primers, Kade suggested using reading posters (Lesetafel) as at the Leipzig Charity School (Leipziger Freischule) and the method described by Johann Christian Dolz. The process should start not with spelling, but with learning simpler syllables and putting them together. The words put together from letters on a panel just under the learners' eyes attracts their attention and makes the process more exciting. The reading panels themselves look like tablets set up at some churches to indicate hymn numbers. ${ }^{113}$

Johann Christian Dolz (1769-I843), whom Kade mentioned, was at that time a deputy director of Ratbsfreischule in Leipzig, and became its director in 1822 . The number of students at the charity school founded in 1792 grew from three hundred to more than five hundred in a couple of years; by 1825 , there were almost a thousand students. Dolz mentioned in his overview of the school's history that even before Stephani's phonic method gained popularity, Karl Gottlieb Plato (1757-I833), the first director of Rabtsfreischule, had used a "natural reading method" instead of the spelling method and had suggested it to the other teachers. Plato also used a so-called reading machine or reading panel (Lesemaschine oder Lesetafel), and according to Dolz, Plato might have got the idea from a preacher at Petershagen, Georg Gieseler. ${ }^{114}$ The reading machine was a panel with horizontal slats, onto which letter tiles were placed. Masing arrived at the same kind of solution independently, as we know from his letter to Rosenplänter. Such ideas were "in the air" at that time and were "invented" at several places and many times.

Among Masing's linguistic influences, one name clearly stands out - David Etienne Choffin (1703-1773), whose significance will be

II3 Kade, F. W. Die lettische Industrieschule, I2-I3.

II4 [Plato, K. G.] Einige Gedanken über die gewöhnlichen Abcbücher in unsern vaterländischen Schulen nebst einer kurzen Beschreibung und Abbildung der Lesemaschine welche in der Leipziger Freyschule gebraucht wird. J. A. Barth, Leipzig, I797; Dolz, J. C. Die Rathsfreischule in Leipzig während der ersten fünfzig Jahre ihres Bestehens. Georg Wigand, Leipzig, I841, 37-38, 52-53. About the dispute on who should take the credit for inventing the reading machine, see Abgeforderte Erkärungen der Lesemaschine betreffend. - Bibliothek der Pädagogischen Literatur [...]. Hrsg. von J. C. F. Guts Muths. Bd. I. J.

Perthes, Gotha, 1802, 210-219. 
elaborated here. In a letter to Rosenplänter, Masing mentions that among those who research the Estonian language, nobody is able to compile such a grammar as Choffin had compiled for the French language. According to Masing, Choffin's book, which was published in 1743 and appeared in three prints, surpasses everything, "even what the Académie Française has written about its own language". ${ }^{115}$ Choffin was a teacher of French at Halle University, where his books were in use when Masing studied there. The grammar 'given' by Choffin mentioned by Masing was actually compiled by Georg Sarganeck (1702-1743), a Pietist pedagogue in Halle, following the example of a Latin grammar book, the author of which was Joachim Lange (1670-1744), who had also worked in Halle. What most deeply impressed Masing in "Verbesserte GRAMMAIRE RAISONÉE" 116 was its theoretical part, which in his opinion could only be used by scholars: "We are now able to provide only grammatical aphorisms [about the Estonian language] and this situation will last for a long time". ${ }^{117}$ The Grammar consists of three parts: I) Grammaire Raisonée, 2) Grammaire Pratique and 3) Dictionaire en Abrégé. The work is compiled following the principles of universal grammar, which is also highlighted in orthography. The first rule in the chapter about orthography says: "If at all possible, write as you speak, and vice versa." The third rule says that all letters that are not pronounced should be left unwritten, except in the case it causes confusion and misunderstanding. ${ }^{118}$ The principles expressed by these rules as well as the pursuits for universality and rationality were also followed by Masing. Heli Laanekask connects Masing's views with the tradition of philosophical grammars that started in the seventeenth century, which were most prominently represented by French linguists. ${ }^{119}$

This proposition might need further clarification. The tradition of general grammars started with Grammaire générale et raisonnée (1660) by the Port-Royal scholars Antoine Arnauld and Claude Lancelot. ${ }^{120}$ The

II5 OWM to JHR, IV/220 (I March I824).

II6 [Sarganeck, G.] Verbesserte GRAMMAIRE RAISONÉE, Oder: Erleichterte Französische Sprachlehre, nach der Methode und Ordnung der Langischen Grammatic eingerichtet. Halle, Verlag des Weisenhauses, 1758 (first print 1743, third print 1769); see Stengel, E. Chronologisches Verzeichnis französischer Grammatiken vom Ende des I4. bis zum Anfange des 18. Jahrhunderts [...]. John Benjamins, Amsterdam, 1976, 87; Francke, A. H. Schriften über Erziehung und Unterricht. Bearb. von K. Richter. Bd. 2. Siegismund \& Volkening, 1872, 704 .

II7 OWM to JHR, IV/220 (I March I824).

II8 [Sarganeck, G.] Verbesserte GRAMMAIRE RAISONÉE, Vorbericht $\$ 3, \$ 6,60-63$.

II9 Laanekask, H. O. W. Masingu keeleteaduslikust vaatepiirist, I27.

I20 [Arnauld, A., Lancelot, C.] Grammaire générale et raisonnée. Contenant. Les fondemens de l'art de parler; expliqués d'une manière claire et naturelle; Les raisons de ce qui est commun à toutes les langues, et des principales differences qui s'y rencontrent; Et plusieurs remarques nouuelles sur la Langue Françoise. Pierre Le Petit, Paris, 166o; Lancelot, C., 
fifth chapter of the so-called Port-Royal grammar "Of letters considered as characters" presents logically deduced rules of the perfect grammar, which are based on as precise a correspondence of sounds and letters as possible. In the sixth chapter of the grammar "Of a new method for easily learning to read in all sorts of languages”, Lancelot and Arnauld indicate that the names of letters put together do not produce the corresponding sound of the syllable: "It seems then, as has already been noticed by some discerning people, that the most natural way of teaching this would be for those who teach reading at first to children to recognize their letters only by sounds of their pronunciation. [...] Similarly, consonants should be named solely by their natural sound, adding only the mute $e$ [' $e$ muet] which is necessary for pronunciation."121

There is no evidence that Masing knew about the Port-Royal grammar, but its title echoes in the title of his favourite grammar and quite probably this is the same source from which the stumme e through various stages came into his reading sheets. The author of the present article has previously suggested that the Port-Royal grammar might have served as an example for Forselius' new names of letters and his teaching method. ${ }^{122}$ However, this hypothesis is supported only by analogies and indirect connections. The question whether Masing borrowed his method from Forselius and continued the tradition of the late seventeenth century or adopted a similar method after a break in the tradition has no direct answer. The latter seems to be more likely, due to the new arrival of the phonic method in Germany and the fact that actual examples were available. Apart from this, Masing's reading sheets and his Täieline ABD-ramat (1823) did not cause an education turn. To achieve the turn, comprehensive teacher training and a coordinated school network would have been needed. ${ }^{123}$ Thus, the phonic method was taken into use as 'new' once again here too. In 1867, Carl Robert Jakobson's Uus Aabitsaraamat (A New Primer: Learn Reading and Writing in Fifty Days) was published declaring that the days of the spelling method (Buchstabiermethode) were over. ${ }^{124}$ The consonant names with the unpronounced e, which were used by Forselius and Masing, were at some places in south Estonia still in use in the I930s. ${ }^{125}$

Antoine, A. General and Rational Grammar. The Port-Royal Grammar. Ed. and trans. by Jacques Rieux and Bernard E. Rollin. Mouton, The Hague, Paris, 1975.

I2I Lancelot, C., Antoine, A. General and Rational Grammar, 56-6I.

I22 Pôldvee, A. I7th Century Estonian Orthography Reform, IO-II.

I23 About the choice and use of school textbooks, see Paatsi, V. Kooliraamatute loendus I843. aastal Tartu- ja Vórumaal. Tartumaa Muuseum, Tallinn, I99I.

I24 Jakobson, C. R. Uus Aabitsaraamat, kust wiiekümne pääwaga lugema ja kirjutama wốib óppida. [C. R. Jakobson], Peeterburgis, 1867.

I25 Wieselgren, G. B. G. Forselius, 77-78 (fn. 39, information by Paul Ariste). 
It has previously been assumed that this might have been the duration of the tradition of the seventeenth century, but now we also need to consider the possibility that Otto Wilhelm Masing helped to keep this tradition alive, or that he revived it.

\section{CONCLUSION}

The era of the Enlightenment, or the "pedagogical century", did not leave the Baltic provinces of Russia untouched. Although this sounds a trivial recognition, there is still not a detailed picture of the first contact between Estonian (and Latvian) schools and progressive education and educational innovations. In history, new pedagogical ideas as well as methods of teaching and upbringing spread through networks of clergymen and literati during the Reformation of the sixteenth century and the early Enlightenment of the seventeenth century, and even more intensely during the 'real' Enlightenment. Therefore, an international and transnational context is the natural prerequisite and inevitable methodological approach of research into the history of education ideas. This viewpoint is still very little represented in Estonian school historiography of the eighteenth and nineteenth centuries, especially the approaches to peasant education, which means that important pedagogical influences and connections have not been highlighted. The most prominent example is Otto Wilhelm Masing, a leading figure in Estonian cultural history, with one of the key elements of his teaching method not even noticed.

In the Baltic provinces, Estonian and Latvian peasants were intertwined with a German-speaking elite, German culture and the Russian empire, resulting in a society that consisted of different ranks in several provinces that were of a multilingual, multicultural and hybrid nature. Narrow national subject matter and outlook are not sufficient to research developments in the history of the Baltic provinces, something that has been more clearly understood during recent decades. In addition, broader horizons and the transnational perspective, interdisciplinarity and the vertical dimension of history should not be forgotten in research because they help to view the object of research from various angles, as well as its genetic development and sometimes its repetition. All of this holds true for the research into the Estonian lands during the early nineteenth century. Apart from local school history such research has to include more general pedagogical and didactic trends as well as social and 
linguistic aspects. During that time, examples from abroad were adapted to local circumstances and translated into local languages.

In any case, the context of the Russian empire also has to be taken into account. Thanks to the liberal attitudes of emperor Alexander I, the beginning of the nineteenth century was a favourable time for the reception of new ideas in the Baltic provinces. However, the initial surge and optimism faded when Russia entered the Napoleonic wars. One of the pedagogical examples of the period were the ideas of Johann Heinrich Pestalozzi, whose influence increased thanks to the support of Frédéric-César de La Harpe and Georges Frédéric Parrot, the emperor's councillors. Parrot became the rector of Tartu University, re-opened in I802, and was a member of the school commission responsible for the education arrangements of nearby provinces. In I804, Parrot invited Pestalozzi to Tartu to carry out a school reform, but Pestalozzi refused. The teaching method close to nature and related to work, which originated from Pestalozzi's writings, was first presented in the textbook Weikenne oppetusse nink luggemisse Ramat (1805) by George Gottfried Marpurg, a pastor at Vastseliina. This was the first time that more varied secular learning materials were introduced to the children of Estonian peasants.

The Industrieschule movement initiated by the Bohemian clergyman Ferdinand Kindermann, which started in Austria, seems to have been the main influence on the parish school opened by Johann Philipp von Roth, a pastor at Kanepi. This also inspired the brochure Die lettische Industrieschule (1805) by Kuldīga's provost Friedrich Wilhelm Kade, which was an alternative to Parrot's project of setting up parochial schools. Neither of the plans was carried out. However, the transnational horizon of the education ideas was much wider than the German cultural area. Otto Wilhelm Masing and Johann Heinrich Rosenplänter, whose correspondence has provided the main source of the present article, tried to adapt the Bell-Lancaster method, which had started in India and England, to Estonian schools. When serfdom was abolished in Livland province in $18 \mathrm{I} 9$, this gave hope that there would be new opportunities to educate peasants. Masing saw Lancaster schools in Riga and his textbook Luggemisse lehbed (182I) was inspired by posters used in these schools. In his teaching manual and elsewhere, Masing also mentions schools in India, where writing was taught on sand tables. In Estonian peasant schools, there was no need to apply the mechanical system of mutual instruction typical of Lancaster schools with hundreds of students. However, Masing took into use a primer with printed alphabet tiles, which 
was called Lesemaschine in Germany. In Masing's case, the influences of the Bell-Lancaster method have briefly been mentioned, but we would rather have to agree with Masing's own opinion as well as Rosenplänter's that it was an adaptation - it was Masing's own method, which was only inspired by distant examples. The attempts made by Masing and several others can also be regarded from an anthropological viewpoint as a cultural translation. When ideas or methods are borrowed, filters caused not only by mediators and languages, but also by social circumstances and cultural differences have to be overcome. A part of the text can be lost in translation or remain quite untranslatable. However, it was via Masing's writings that information about the transnational pedagogical innovation initiated by "clever men" in India and England reached the Estonian reading public.

One aspect of Masing's method that has been entirely overlooked and never researched is connected with the phonic method, which re-emerged in literacy teaching in Germany in the late eighteenth and early nineteenth centuries. In Masing's reading sheets and in his primer of I823, the consonant names are not ka-el-em, etc., but ke-le-me, etc., with an unpronounced e (stummes e). It is not clear if this method originated from the Dessau pedagogues J. B. Basedow and L. H. F. Olivier or was it B. G. Forselius' method used in the mid-168os in Estonian schools and based on the same letter names and syllable-by-syllable reading that served as an example for Masing. One of Masing's - and also Forselius' - aims was a phonetically exact written language; Masing also added the letter ó into the Estonian alphabet, which had been missing. Masing highly appreciated the rational French grammar, the traditions of which were started by the so-called Port-Royal grammar ( 1660 ), which might have been one of Forselius' exemplars or at least indirectly influenced him.

From a longer historical perspective, the problems that needed solutions when educating peasants in Estland and Livland at the beginning of the nineteenth century were by and large similar to those that came up during the last quarter of the seventeenth century, and thus several solutions were similar. The previous eastern provinces of Sweden had become the western governorates of Russia. Instead of orthodox Lutheranism, the pedagogical principles of the Enlightenment dominated the discourse of pedagogical innovation, although serfdom still prevailed, as did the central role of the church in peasant education. In several ways progress characteristic of the period of the Enlightenment turned out to entail re-discovering or re-inventing old methods. After serfdom was abolished, people's education was gradually re-arranged. 
From the I830s and I840s onwards there are more examples of attempts at progressive education, for example the Bell-Lancaster system and other educational innovations in schools, although this later and wider movement is not discussed within the frames of the present article.

\title{
Acknowledgments
}

The preparation of this article has been supported by the Estonian Research Council's research project IUT316, A Transnational Setting for Estonian History: Transcultural Entanglements, International Organisations and Transborder Migrations (I6th-2Ist Centuries).

\author{
EESTIKEELNE HARIDUS JA \\ PEDAGOOGIKAUUENDUSED \\ I9. SAJANDI ALGUL. \\ RAHVUSVAHELISED MÓJUD JA \\ AJALOOLISED JUURED
}

Aivar Pôldvee

Valgustusaeg kui “pedagoogiline sajand”, nagu seda iseloomustas Saksa reformipedagoog Joachim Heinrich Campe, ei läinud mööda ka Balti provintsidest. Ometigi puudub seni üksikasjalikum pilt eesti (ja läti) koolide esimestest kontaktidest reformipedagoogika ja haridusuuendusega. Uued pedagoogilised ideed, ópetamis- ja kasvatusmeetodid on ajaloos levinud mööda vaimulike ja haritlaste vôrgustikke, nii oli see I6. sajandil reformatsiooni ja I7. sajandil varase valgustuse ajal, aga veel intensiivsemalt "päris" valgustusajal. Rahvusvaheline ja rahvusülene kontekst on seetôttu haridusideede ajaloo uurimise loomulik eeldus ja vältimatu metodoloogiline lähenemisviis. Haritlaste vôrgustike ja (Jan Amos Komenský) ideede leviku uurimise üks algatajaid oli Tartu ülikooli ajaloolise usuteaduse professor Ján Radomil Kvačala, eesti historiograafiast saab esile tôsta Arvo Teringu, Indrek Jürjo ja Epi Tohvri töid. Eesti kooliajaloos, eriti I8.-19. sajandi talurahvahariduse käsitlustes, on selline vaade vähe esindatud ja olulised pedagoogilised mõjud põhjalikult uurimata. Markantseim näide on kultuuriloo suurkuju Otto Wilhelm Masing, kelle ópetamismeetodi üht vôtmeelementi pole seni isegi mitte märgatud. 
Balti provintsides oli eesti ja läti talurahvas põimitud saksakeelse eliidi, saksa kultuuriruumi ja Vene impeeriumiga, mis andis mitmesse provintsi jagatud seisuslikule ühiskonnale mitmekeelse, multikultuurse ja hübriidse iseloomu. Kitsalt rahvuslik ainevalik jääb siinse ajaloo uurimisel piiratuks, nagu viimastel aastakümnetel on üha selgemalt môistetud. Avarama horisondi ja transnatsionaalse perspektiivi kõrval ei tohiks uurimistöös unustada interdistsiplinaarsust ja ajaloo vertikaalset mõoódet, mis aitab näha uurimisobjekti mitmest küljest, geneetilises arengus ja vahel ka kordumises. Kôik see kehtib 19. sajandi alguse eestikeelse hariduse uurimise kohta, mis peab lokaalse kooliajaloo kõrval silmas pidama mitte ainult üldisemaid pedagoogilisi ja didaktilisi trende, vaid ka sotsiaalseid ja lingvistilisi aspekte. Välismaised eeskujud, mille puhul n-ö sildid levisid kiiremini kui sisu, tuli sobitada kohalike sotsiaalsete oludega ning tôlkida kohalikesse keeltesse ja kultuurikonteksti, seetôttu oli paratamatu, et môndagi läks "tôlkes kaduma”, aga sündis ka originaalseid lahendusi.

19. sajandi algus oli Balti provintsides tänu Vene keisri Aleksander I liberaalsetele hoiakutele uute ideede vastuvôtuks soodne. Esialgne hoog ja optimism raugesid, kui Venemaa sekkus Napoleoni sôdadesse. Üks pedagoogilisi eeskujusid oli Johann Heinrich Pestalozzi, kelle môju aitasid suurendada keisri nôuandjad Frédéric-César de La Harpe ja Georges Frédéric Parrot. Parrot sai I802. aastal avatud Tartu ülikooli rektoriks ja kuulus koolikomisjoni, mille ülesanne oli korraldada ümberkaudsete provintside hariduselu. 1804. aastal kutsus Parrot Pestalozzit Tartusse appi koolireformi läbi viima, millest Pestalozzi ära ütles. Pestalozzist lähtunud looduslähedane, kodu ja tööga seotud ópetamismeetod leidis eesti keeles esimese väljenduse Vastseliina pastori George Gottfried Marpurgi ópperaamatus Weikenne oppetusse nink luggemisse Ramat(I805). Selles jốudis eesti talulasteni esimest korda mitmekesisem sekulaarne óppematerjal.

Kanepi pastori Johann Philipp von Rothi avatud kihelkonnakooli eeskuju tuleb otsida eeskätt böömi vaimulikust Ferdinand Kindermann von Schulsteinist Austrias alguse saanud Industrieschule liikumisega. Sellest on inspireeritud ka Kuldīga praosti Friedrich Wilhelm Kade brošüür Die lettische Industrieschule (1805), mis kujutas endast alternatiivi Parrot' kihelkonnakoolide kavale. Ellu viimata jäid need môlemad. Haridusideede transnatsionaalne horisont ulatus aga palju kaugemale saksakeelsest kultuuriruumist. Indiast ja Inglismaalt alguse saanud Bell-Lancasteri ehk vastastikuse ópetamise meetodit püüdsid eesti koolioludele kohandada Otto Wilhelm Masing ja Johann Heinrich Rosenplänter, kelle publitseeritud ja kommenteeritud (Leo Anvelt jt) kirjavahetus on siinse käsitluse üks põhiallikaid. Pärisorjuse kaotamine 
Liivimaal I819. aastal suurendas lootust, et talurahva harimiseks avanevad uued võimalused. Lancasteri tüüpi kooliga tutvus Masing Riias, tema Luggemisse lebhed (I82I) olid inspireeritud seinatabelitest, mida sellistes koolides kasutati. Masing nimetab oma ópetamisjuhendis jm ka India koole, kus kirjutamist ópetati liivalaual. Vastastikuse ôppe masinlikku süsteemi, mis iseloomustas sadade ópilastega Lancasteri koole, polnud vaja eesti talurahvakoolis rakendada. Küll aga kasutas Masing seinale riputatavaid plakateid ja oma versioonis liikuvat aabitsat, mida Saksamaal nimetati Lesemaschine. Bell-Lancasteri eeskuju on Masingu puhul pógusalt mainitud, aga pigem tuleb nóustuda Masingu enda ja Rosenplänteri hinnanguga, et tegemist oli mugandusega ehk "Masingu meetodiga”, mis sai kaugetest eeskujudest üksnes inspiratsiooni. Küll aga jõudis Masingu sule läbi esimest korda eesti ajalehelugeja ette kirjeldus India ja Inglismaa "tarkade meeste" algatatud rahvusülesest pedagoogikauuendusest.

Masingu meetodi seni täiesti märkamata ja käsitlemata aspekt seondub häälikumeetodiga, mis lugemaópetamisel ı8. sajandi lópul ja 19. sajandi algul taas Saksamaal aktuaalseks muutus. Masingu lugemise lehtedes ja aabitsas (I823) on kaashälikute nimeks mitte ka-el-em jne, vaid tumma e-ga ke-le-me jne. Ei ole selge, kas see vôte pärineb Dessau pedagoogidelt Johann Bernhard Basedow'lt ja Ludwig Heinrich Ferdinand Olivier'lt vối oli Masingu eeskujuks i68o. aastate keskpaiku eesti koolides Bengt Gottfried Forseliuse poolt kasutusele vôetud meetod, mis pôhines samadel tähenimedel ja silpide kaupa lugemisel. Masing taotles foneetiliselt täpset kirjakeelt, nii nagu ka Forselius, ning ta lisas eesti alfabeeti seni puudunud ô-tähe. Masing hindas kõrgelt ratsionaalset prantsuse grammatikat, millisele traditsioonile pani aluse nn Port-Royali grammatika (I660), mis vôis olla ka Forseliuse üks mójutajaid.

Pikemas ajaloolises perspektiivis püüti 19. sajandi alguses Eestija Liivimaa talurahva harimisel lahendada üsna samu probleeme, mida 17. sajandi viimasel veerandil, seetôttu olid ka mitmed lahendused sarnased. Rootsi idapoolsetest provintsidest olid saanud Venemaa läänepoolsed kubermangud, ortodoksse luterluse asemel domineeris haridusuuenduse diskursis valgustuspedagoogika, aga saksakeelne eliit, pärisorjuslik kord ja kiriku keskne roll talurahva harimisel püsisid endiselt. Valgustusajastule iseloomulik progress osutus siin moodsa kultuuritôlke kôrval mitmes aspektis uuesti avastatud või uuesti leiutatud vanaks. 